\title{
Upper Paleocene ultramafic igneous rocks offshore mid-Norway: Reinterpretation of the Vestbrona Formation as a sill complex
}

\author{
Amer Hafeez ${ }^{1}$, Sverre Planke², Dougal A. Jerram ${ }^{3}$, John M. Millett ${ }^{4}$, Dwarika Maharjan ${ }^{5}$, and Tore Prestvik ${ }^{6}$
}

\begin{abstract}
Continental breakup between northwest Europe and Greenland (approximately $56 \mathrm{Ma}$ ) was associated with widespread magmatism. Silica undersaturated alkaline porphyritic igneous rocks of a similar age have previously been dredged near the mid-Norwegian coast. These igneous rocks of the Vestbrona Formation have previously been interpreted as either igneous plugs or volcanic flows. New 3D seismic data indicate that relatively small sill complexes are abundant in the same region. In total, 36 sills with a size of $0.1-9 \mathrm{~km}^{2}$ have been mapped. In addition, 10 seismic horizons were interpreted and tied to nearby wells to obtain a robust stratigraphic framework. The sills mainly intrude Cretaceous and Paleocene sequences; however, one sill is also identified in the preCretaceous sequences. The sills locally form erosional remnants on the seabed due to massive uplifting and erosion of the continental margin. Vintage igneous and sedimentary dredge samples have been reanalyzed, including petrography, geochemistry (X-ray fluorescence [XRF], X-ray diffraction [XRD]), biostratigraphy, and Ar-Ar geochronology. The new Ar-Ar data suggest that the sills are 1-2 Ma older than breakup (approximately 57-58 Ma). Furthermore, the biostratigraphy and petrography of two sediment samples suggest that the samples were collected from near in situ subcrops and not of an ice rafted origin. The sediment samples are of Danian age and are strongly metamorphosed, most likely by contact metamorphism resulting from heating during sill emplacement. The newly identified sills have implications for the petroleum prospectivity of the study area including source rock maturation within thermal aureoles and the long-term alteration of fluid migration pathways.
\end{abstract}

\section{Introduction}

Volcanic rifted margins, such as those within the North Atlantic Igneous Province (NAIP), are associated with voluminous igneous activity (Saunders et al., 1997; Menzies et al., 2002). The NAIP contains volcanic rocks emplaced during the Late Paleocene to Early Eocene, just prior to and at the onset of rifting between Greenland and Europe (Saunders et al., 1997; Hansen et al., 2008). These events are associated with extensive subaerial volcanism as well as the development of volcanic centers and sill complexes (Planke et al., 2000; Jerram and Bryan, 2015; Schofield et al., 2015). The Norwegian margin of the NAIP is a classic example of a volcanic rifted margin (Planke et al., 2000; Abdelmalak et al., 2016), in which extensive sill complexes $\geq 80,000 \mathrm{~km}^{2}$ in size have been identified, intruding mainly into thick sedimentary basin successions such as the Vøring and
Møre Basins (Planke et al., 2005). These intrusions are commonly associated with hydrothermal vent complexes, which provide evidence for the thermal maturation of host sediments within the sill aureoles causing gas generation and release (Jamtveit et al., 2004; Svensen et al., 2004; Aarnes et al., 2012). Clearly, the timing and location of sill complexes are important because they play a role in modifying the thermal history within a basin and directly affect petroleum systems where present (Schofield et al., 2016; Senger et al., forthcoming).

Assessing the relative timing and impact of sills and other intrusions within sedimentary basins can be a challenge. The subsurface sills themselves are intersected relatively rarely by wells, and they are even less commonly cored (Aarnes et al., 2015; Schofield et al., 2015), and often the expression of the sills in seismic needs to be constrained by the regional stratigraphic framework

\footnotetext{
${ }^{1}$ Volcanic Basin Petroleum Research, Oslo, Norway and Tullow Oil Norge, Oslo Norway. E-mail: amer@vbpr.no.

${ }^{2}$ Volcanic Basin Petroleum Research (VBPR), Oslo, Norway and University of Oslo, The Centre of Earth Evolution and Dynamics, Oslo, Norway. E-mail: planke@vbpr.no.

${ }^{3}$ University of Oslo, The Centre of Earth Evolution and Dynamics, Oslo, Norway and DougalEarth, Solihull, UK. E-mail: dougal@dougalearth .com.

${ }^{4}$ Volcanic Basin Petroleum Research, Oslo, Norway and University of Aberdeen, Department of Geology \& Petroleum Geology, Aberdeen, UK. E-mail: john.millett@vbpr.no.

${ }^{5}$ Volcanic Basin Petroleum Research, Oslo, Norway. E-mail: dwarica@vbpr.no.

${ }^{6}$ Department of Geology and Mineral Resources Engineering, NTNU, Trondheim, Norway. E-mail: tore.prestvik@ntnu.no.

Manuscript received by the Editor 9 September 2016; revised manuscript received 25 January 2017; published online 16 May 2017. This paper appears in Interpretation, Vol. 5, No. 3 (August 2017); p. SK103-SK120, 9 FIGS.

http://dx.doi.org/10.1190/INT-2016-0143.1. @ 2017 Society of Exploration Geophysicists and American Association of Petroleum Geologists. All rights reserved.
} 
and any additionally available well control (Schmiedel et al., 2017). The Vestbrona Formation, which forms the focus of this contribution, is located across the central part of the Frøya High, close to the Norwegian coast and away from the main sill complexes on the margin (Figure 1). Within this study, direct sampling and highquality seismic data were used to assess the nature of the igneous rocks forming the Vestbrona Formation.

The Frøya High is defined at the level of the Late Jurassic-Early Cretaceous unconformity, which is gently dipping toward the west-northwest (Blystad et al., 1995). Westward-dipping Mesozoic and Paleogene sedimentary units, overlying high-grade metamorphic basement, form petroleum exploration targets offshore Kristiansund on the mid-Norwegian margin (Figure 1). Several semicircular bathymetric highs or seamounts are located in the study area, the Vestbrona Seamounts (Figure 2). Two of these seamounts were dredged, revealing exotic alkaline volcanic rocks with a K-Ar age of $55.7 \pm$ $0.9 \mathrm{Ma}$ (Bugge et al., 1980). The dredged rock samples were later called the Vestbrona Formation (Askvik and Rokoengen, 1985). The rocks are silica undersaturated alkaline porphyritic igneous rocks and were interpreted as igneous plugs (Prestvik et al., 1999).

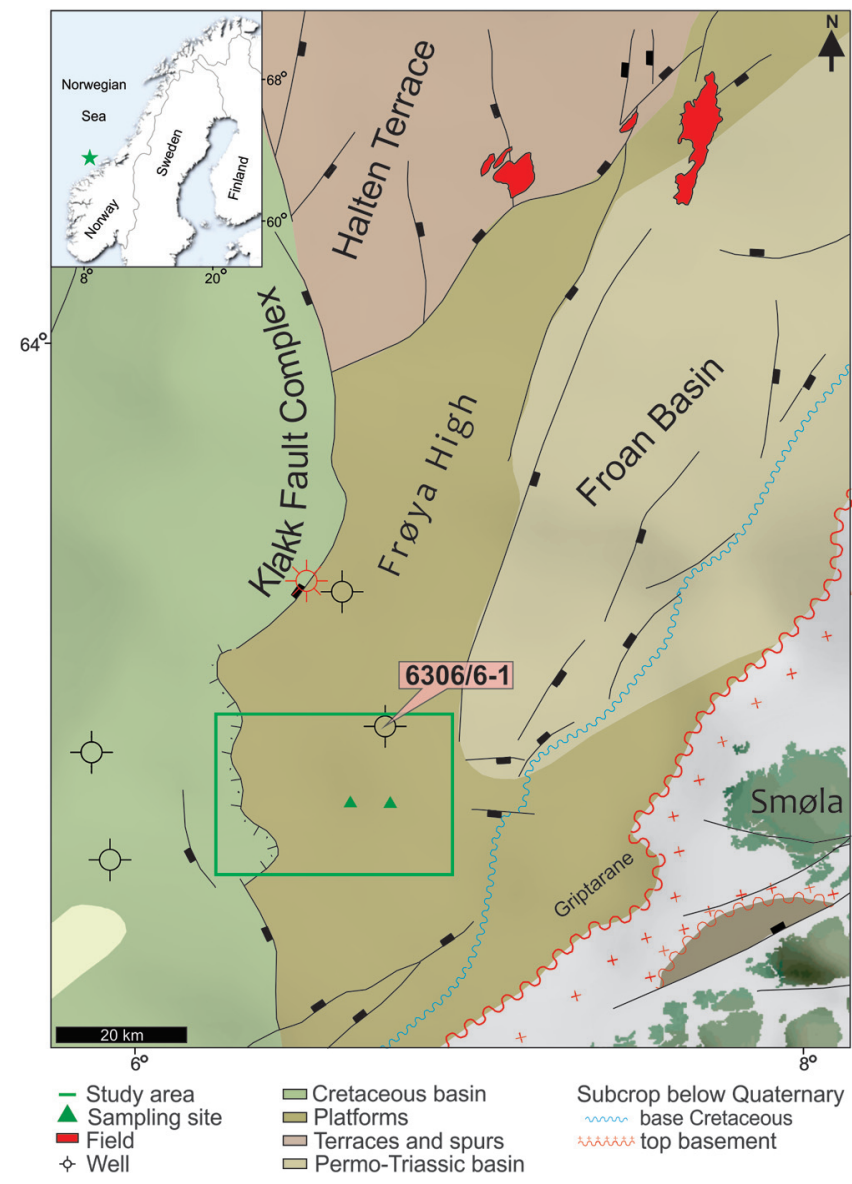

Figure 1. Regional nomenclature map showing the location of study area, key wells and petroleum fields (modified from Trulsvik et al., 2012).
The Vestbrona Formation dredge samples provide valuable information about the nature of the igneous activity and the host rocks. Within this study, we explore the link between these subcropping igneous rocks and their potential expression in the subsurface. Recent $3 \mathrm{D}$ seismic data from the area provide deep seismic images that allow the full context and extent of these exotic igneous rocks to be assessed. This combination of seismic and dredged data allows the extent of the igneous rocks within the Vestbrona Formation to be determined and an informed assessment of the petroleum implications of the igneous activity. Igneous rocks and emplacement processes may have an important impact on the petroleum prospectivity of volcanic basins (Aarnes et al., 2015; Jerram, 2015; Schofield et al., 2015; Senger et al., forthcoming). Specifically to the NAIP, huge volumes of CH4 have been demonstrated to have been generated in the thermal aureoles of sill intrusions (Svensen et al., 2004), results supported by well penetrations of sill intrusions on the Vøring Margin (Aarnes et al., 2015). Key questions exist in terms of the nature and distribution of igneous complexes and the relative dating and time span of the igneous activity in the basin (Trude et al., 2003; Aarnes et al., 2015), the effects of the igneous rocks on diagenesis, maturation, and structure of the sedimentary sequences they intersect (Hansen and Cartwright, 2006; Hansen et al., 2008; Schmiedel et al., 2017), and the impact of igneous rocks and associated vent structures on fluid migration in the basin (Kennish et al., 1992; Svensen et al., 2004; Magee et al., 2016). The combination of 3D seismic data and direct-sampling data offered by the Vestbrona Formation provides the possibility to assess some of these questions along the Norwegian margin.

The aim of this study was to provide documentation of the extent and nature of the Vestbrona Formation, using newly available geochemical, geochronological, and 3D seismic data. Our focus has been on the interpretation of the type and distribution of igneous rocks on seismic 3D data and a reanalysis of existing dredge samples and existing available data for the Vestbrona Formation. A new interpretation of the style of intrusions as well as new age constraints on the timing of the igneous events of the Vestbrona Formation is presented, and the petroleum implications of the new results are further discussed, including suggestions for future study.

\section{Data and Methods Geologic database}

The main database for this project consists of vintage dredge samples and new $3 \mathrm{D}$ seismic reflection data. The dredge samples from the Vestbrona Seamounts have been the focus of several previous studies (Bugge et al., 1980; Torske and Prestvik, 1991; Prestvik et al., 1999). These studies mainly focused on the geochemistry of the basic igneous rocks, and the context of the alkaline centers in relation to the geodynamic lithospheric framework of the area. One sample was dated using the K-Ar method (Bugge et al., 1980), whereas the recovered 
sedimentary rocks have barely been described. Access was given by Norges Teknisk Naturvitenskapelige Universitet (NTNU) to the remaining samples from dredges B77-154/3 and B77-153/2 for new geochemical and geochronological analyses. This includes 17 thin sections, nine powdered samples with various small volumes of material, two sedimentary samples (labeled as 154/3 Sed-1 and 154/ 3 Sed-2), five basic igneous rocks, and a small coarsegrained granitic sample (labeled as xenolith).

\section{Methodology}

New analyses were undertaken for the two sediment samples to help constrain the age, type, and diagenetic state of the rocks. We were particularly interested in checking that the sediment samples were consistent with dredging of samples near in situ and not of ice-rafted origin as previously suggested. Initial sedimentary petrology was carried out by binocular microscope on hand samples, and two thin sections were prepared. The samples were blue-dye stained to highlight connected porosity, where present, and imaged using a digital capturing system at Physics of Geological Processes (PGP), the University of Oslo. An XRD analysis was carried out to help determine the contents and possible clay types of the two sediment samples (analysis by J. M. Hugget at Petroclays, UK). A subsample of each sediment sample was sent off for palynological analysis at APT, Kjeller. A standard palynology preparation procedure was followed.

The original XRF analysis was reported for the Vestbrona samples by Prestvik et al. (1999). Some of the powders used in these original studies were reanalyzed in this study. New major and trace elements for three samples and standards were measured on an ARL 8420+ dual goniometer wavelength dispersive XRF spectrometer in the XRF Laboratory at the Department of Earth Sciences, Open University, Milton Keynes, United Kingdom. The original geochronological age of the Vestbrona Formation, $55.7 \pm 0.9$ m.y., was based on a K-Ar analysis. Such analysis can sometimes suffer from issues associated with excess argon, which potentially gives unreliable ages. In addition, the Ar-Ar dating technique has more recently superseded K-Ar analysis in volcanic rocks due to advances in the precision and accuracy of the analysis (Kelley, 2002). In this study, two samples were identified for analysis using the Ar-Ar technique, 153/2A and 154/3A. The analyses were carried out at Norges Geologiske Undersøkelse (NGU), Trondheim.

\section{Geophysical database}

The geophysical database used for this study consists of conventional $2 \mathrm{D}$ and $3 \mathrm{D}$ seismic, bathymetry, and well data. The total area of the 3D survey (SEN1101) is $1580 \mathrm{~km}^{2}$. Four different versions of the $3 \mathrm{D}$ cube have been available for this study. The quality of the $3 \mathrm{D}$ data is generally good in the sedimentary sequences, down to the Top Basement. Comparison of 2D and 3D data shows that the imaging of the main reflections and the total imaging depth is similar. Bathymetric maps were generated using the shared database of Olex. The maximum water depth in the area is $300 \mathrm{~m}$, and the minimum is $130 \mathrm{~m}$ at the Vestbrona Seamounts. A recent Marine AREA database for Norwegian waters (MAREANO) cruise acquired multibeam bathymetric data across one of the dredging locations (B77-153/2) (Figure 2b). Well data were provided by Tullow Oil (formation tops and velocity-depth curve) and Norwegian Petroleum Directorate. One wildcat well, 6306/6-1, is located within the study area. The main objective of this dry well was to test a potential hydrocarbon accumulation in Late Jurassic Rogn Formation sandstones. However, very good source rocks were encountered. The best source rock was observed in the upper section of Spekk Formation, containing marine anoxic, oil-prone type II kerogen. Lithostratigraphy in wells from the surrounding areas (6306/6-2, 6306/ $5-1,6305 / 9-1$ ) was further used to tie key seismic reflections in the study area.

\section{Seismic interpretation}

The seismic interpretation was done using the IHS Kingdom Suite software. Ten key horizons, sill intrusions, and pipe-like piercement structures were interpreted on every 50th line (inline and crossline) of the $3 \mathrm{D}$ cube. Horizon interpretation focused on strong, continuous reflections that could be correlated over large areas. Horizon interpretations were not extended through areas with low interpretational confidence and reflection continuity. Some events, most notably Intra-1 and Intra-2, were picked as facies unit boundaries, e.g., between units of disrupted, high-amplitude reflections and low-amplitude, nearly transparent units. The key horizons were tied to one well within (6308/6-1) and several other wells around the 3D area for stratigraphic control. The horizons were subsequently gridded using flexible and spline gridding functions, followed by grid to horizon and horizon snap. Different horizon and volume attributes were then calculated (e.g., horizon and root-mean-square [rms] volume amplitudes).

Sill intrusions were interpreted and mapped based upon the reflection characteristics and methods described by Planke et al. (2005, 2015) (Figure 4). The sills were classified based on their stratigraphic levels, and their extents were drawn using the culture management tool.

\section{Geologic Framework Vestbrona Formation}

The Vestbrona Formation (Askvik and Rokoengen, 1985 ) is a sequence of igneous rocks present offshore mid-Norway, near Kristiansund (Figure 2). They occur within Paleogene sedimentary sequences that overlie Precambrian basement gneiss. The Vestbrona Formation was first discovered in 1975 when a series of seamounts were identified approximately $60 \mathrm{~km}$ off the Norwegian coast with elevations up to $80 \mathrm{~m}$ above the sea floor (Bugge et al., 1975; Bugge and Rokoengen, 1976). Similar structural anomalies are also identified within the underlying sedimentary sequence, which did not penetrate the sea surface. The seamounts were subsequently sampled 
in a dredge study by Bugge et al. (1980), and exotic alkaline porphyritic igneous rocks were recovered. These rocks are highly silica undersaturated and gave a K-Ar age of $55.7 \pm 0.9 \mathrm{Ma}$ (Bugge et al., 1980). Prestvik et al. (1999) perform a more detailed geochemical analysis of the dredged rock types and find a mix of olivine-rich nephelinites and basanite rocks.

The alkaline rocks of the Vestbrona Formation are related to the igneous activity of the NAIP, which accompanied continental breakup between Europe and Greenland during the late Paleocene to early Eocene (Saunders et al., 1997; Jerram and Widdowson, 2005; Nelson et al., 2015). Seismic reflection studies reveal that this breakup was associated with widespread sill complexes (Planke et al., 2005; Schofield et al., 2015).
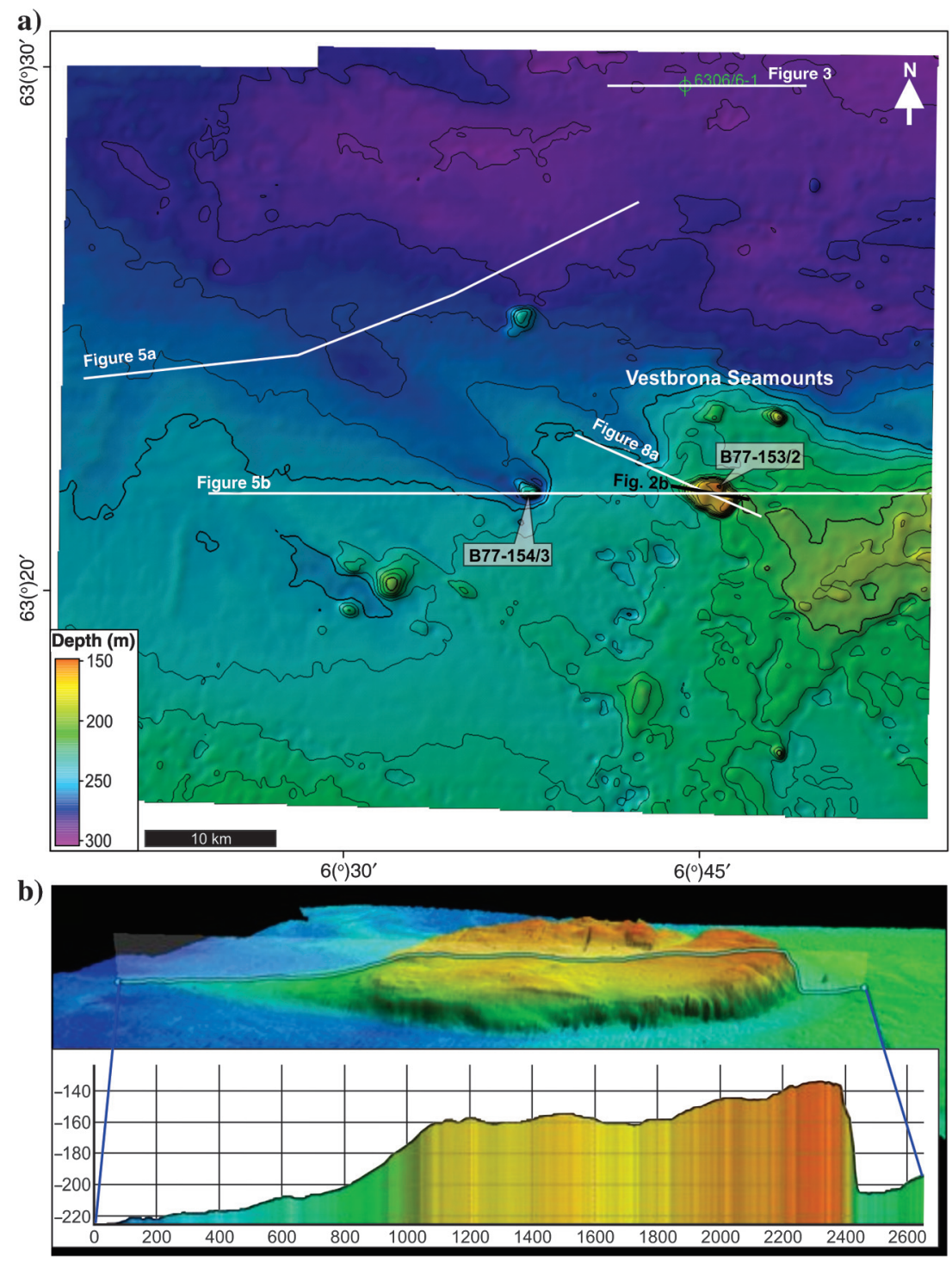

Figure 2. (a) Seabed bathymetry from seismic mapping showing seamounts (the Vestbrona Seamounts) and the location of sampling sites and seismic examples. (b) Multibeam data across sampling location B77-153/2 showing one of the Vestbrona Seamounts, which is $1400 \times 1100 \mathrm{~m}$ wide and rises from the seafloor. The tail on the left side is most likely glacially deposited sediments. Modified from Thorsnes et al. (2012).
Igneous rocks associated with the NAIP are dominantly tholeiitic by volume with occurrences of alkaline affinity being much more volumetrically and spatially restricted. Occurrences of alkaline rocks from elsewhere in the NAIP include examples from East Greenland and the Hebrides, Scotland (Nielsen, 1987; Hole and Morrison, 1992; B. G. J. Upton, personal communication, 2012).

The Vestbrona Formation is located along, but beyond, the southeastern trend of the Jan Mayen Fracture Zone (JMFZ). The igneous rocks are not located near any other igneous centers on the mid-Norwegian margin and represent the most proximal Paleogene igneous deposits to the Norwegian coast. This observation, along with the location of alkali rocks on East Greenland beyond the northwestern trend of the JMFZ, led Torske and Prestvik (1991) to speculate that deepseated continental scale structures existed. These structures were interpreted to have facilitated the focusing and migration of the undersaturated alkali melts, prior to the onset of rift separation and seafloor spreading. The petrogenesis of alkaline magmas may be highly variable (Fitton and Upton, 1987). In the case of the Vestbrona Formation, melting is proposed to have occurred due to decompression enhanced volatile enrichment of the lithospheric mantle within these deep seated structures prior to melting in the Paleogene (Torske and Prestvik, 1991). Volatile addition has the effect of lowering the mantle solidus to promote melting, which would have been further enhanced by the elevated mantle temperatures associated with the NAIP (Torske and Prestvik, 1991; Hole and Millett, 2016). Based on isotopic arguments, however, Prestvik et al. (1999) propose that, although this model fitted the basanites, the nephelinites may have been produced by small degrees of partial melting of a plume-derived asthenospheric mantle component.

\section{Tectonostratigraphy}

After extensional tectonic episodes during the Late Permian to Mid-Jurassic time over the Norwegian Sea margin, a major regional tectonic phase started in the Late Jurassic and continued into the latest Ryazanian times with the rise of regional sea level and deposition of organic-rich shales like the oil prone Spekk Formation (Karlsen et al., 1995; Underhill, 1998; Brekke et al., 2001; Gabrielsen et al., 2001; Kyrkjebø et al., 2004; Müller et al., 2005; Smelror et al., 2007). The erosion of tectonic fault blocks appears as a regional unconformity, the Base 
Cretaceous Unconformity (BCU), which was buried during the Cretaceous by condensed carbonates and siliciclastic sediments as faulting continued and was followed by crustal subsidence and the formation of the deepmarine Møre and Vøring Basins during the Cretaceous (Blystad et al., 1995; Brekke et al., 2001; Smelror et al., 2007).

During Maastrichtian to the Early Paleocene, a prominent phase of uplift occurred and thick delta-like wedges prograded from platforms into the basin and, downlapping on the Base Tertiary Unconformity (BTU), deposited at the intrabasinal slopes during the Danian (Egga Member) (Vergara et al., 2001; Lien, 2005; Martinsen, 2008; Nøttvedt and Johannessen, 2008). Crustal extension during the Late Paleocene culminated with continental separation in the Early Eocene and the initial opening of the Norwegian-Greenland Sea. Renewed regional uplift of the marginal areas of the developing Norwegian-Greenland Sea accompanied breakup (Lundin and Doré, 1997; Doré et al., 1999; Brekke et al., 2001; Smelror et al., 2007). Large-scale thermal uplift associated with the proto-Icelandic thermal anomaly is also proposed during the Late Paleocene to Early Eocene (Saunders et al., 2007), with some researchers arguing for multiple short-lived pulses of uplift (Hartley et al., 2011). During continental rupture, extensive eruptive and intrusive igneous activity affected the developing rifted margins with subareal lavas, hyaloclastite deltas, extensive sill complexes, and high-velocity lower crustal intrusions being emplaced (Planke et al., 2000; Gernigon et al., 2006). The extensive volcanism associated with the volcanic rifted margins is generally associated with higher than ambient mantle temperatures associated with the proto-Icelandic thermal anomaly (Hole and Millett, 2016); however, a lower temperature hypothesis also exists (Foulger and Anderson, 2005). The distribution and magnitude of igneous rocks are also related to the distribution of lithospheric thickness variations, which vary markedly along the conjugate margins due to asymmetric rifting and the inherited structure (Howell et al., 2014; Hole and Millett, 2016).

The basins along the eastern margin of the Norwegian Sea experienced compressional tectonics in the Middle Eocene/Early Oligocene and another in Middle Miocene (Lundin and Doré, 2002). During Late Miocene-Early Pliocene, the Molo Formation developed as a result of mid-Miocene compression and uplift in mainland Norway (Brekke et al., 2001; Eidvin et al., 2007). The Late Neogene was tectonically a very active period with the Norwegian mainland affected by $\mathrm{km}$-scale uplift, extensive erosion, and development of prograding clinoforms (Naust Formation) along the shelf offshore mid-Norway as a result of several glaciations in Plio-Pleistocene time (Rise et al., 2005; Smelror et al., 2007; Hafeez, 2011; Faleide et al., 2012).

\section{Petroleum plays}

The most prominent petroleum play in the area belongs to the Middle and Upper Jurassic Viking Group (Melke, Rogn, and Spekk Formations). The play is known to contain good-quality reservoirs elsewhere that are currently being produced in the Draugen field northeast of the study area (Norwegian Petroleum Directorate, 2016b). The Paleocene play containing the Danian sandstones of the Egga Member is also present in the area. The main reservoir of the Ormen Lange field to the west of the study area is sandstones of Paleocene age in the Egga Member (Norwegian Petroleum Directorate, 2016a). The Egga Member is eroded by repeated glaciations along the midNorwegian shelf and pinching with the Upper Regional Unconformity (URU). Speculative plays in the region include weathered basement rocks of the Frøya High and Triassic or Paleozoic plays in the Frøya Basin.

\section{Seismic Interpretation Results Horizons and sequences}

Ten key horizons plus sills and piercement structures were interpreted on the 3D data. Seven of the horizons were tied to the well 6306/6-1 in the study area (Figure 3); other regional horizons are shown in Figure 4a. Furthermore, seismostratigraphic units are interpreted on the basis of amplitude and continuity of reflections,

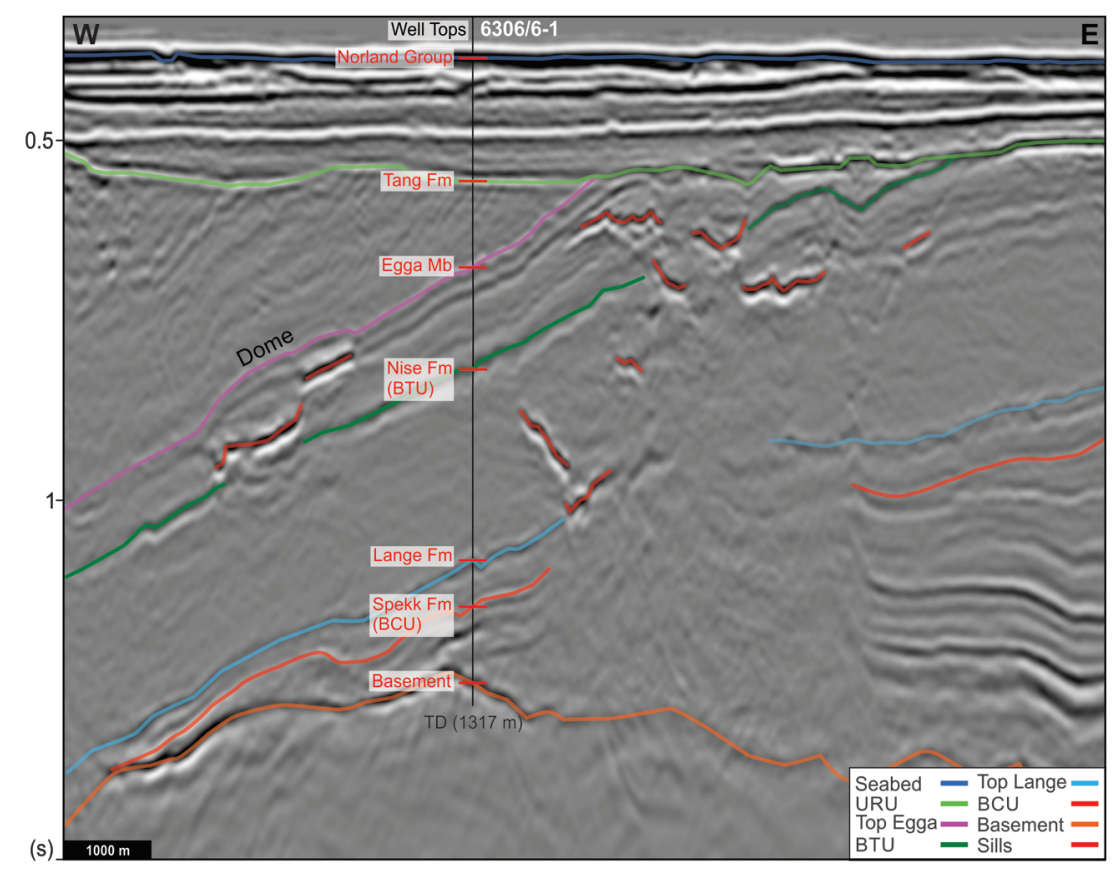

Figure 3. Seismic well-tie profile showing the stratigraphic framework of the study area. Also note the sill complexes in Cretaceous and Paleocene sediments and the doming of the Top Egga reflection above an intra-Egga saucer-shaped sill. See Figure 2 for the location. 


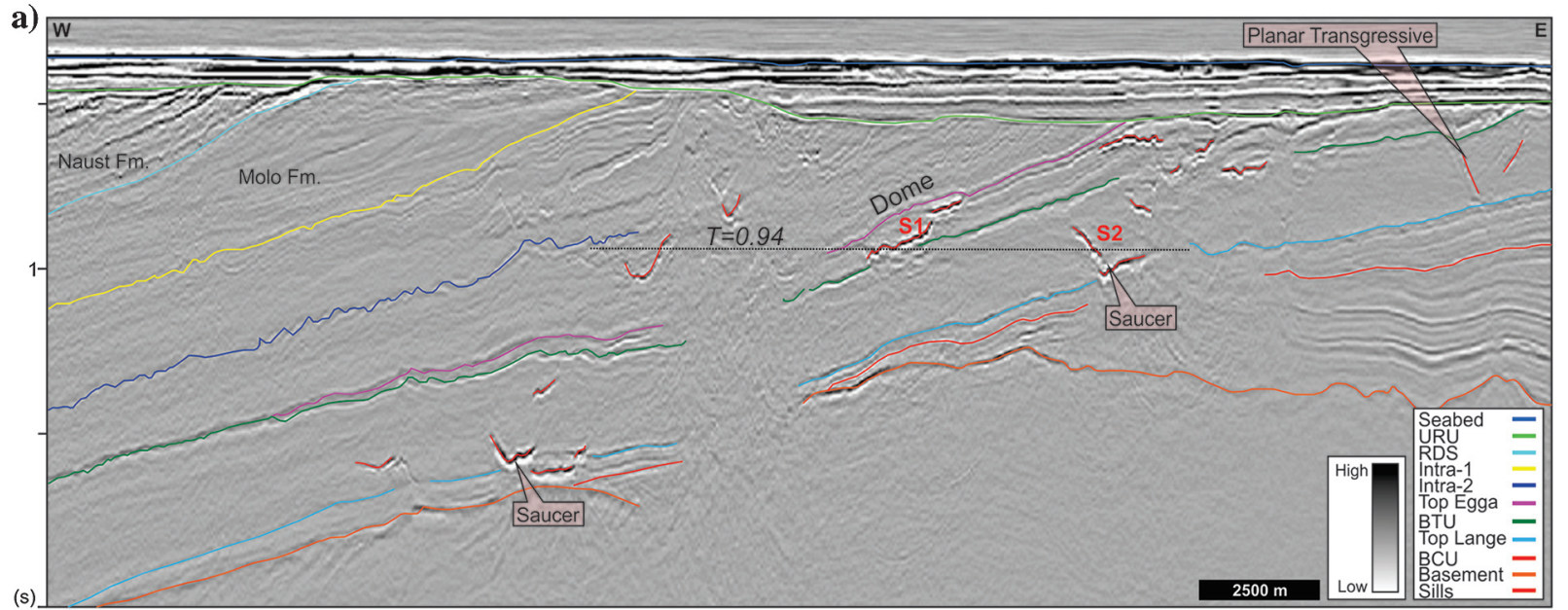

b)

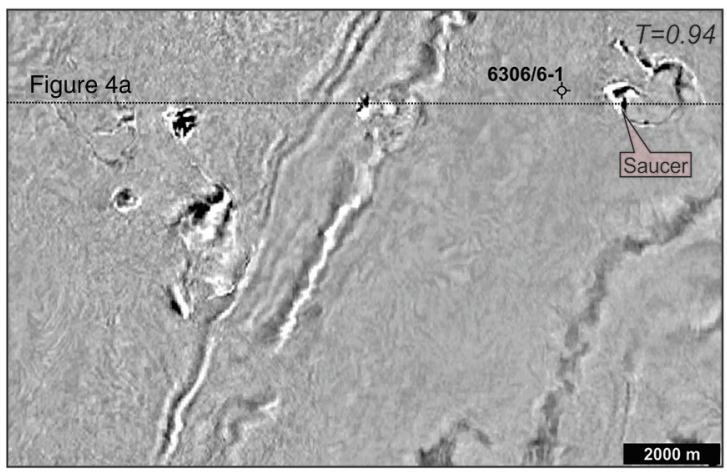

d)

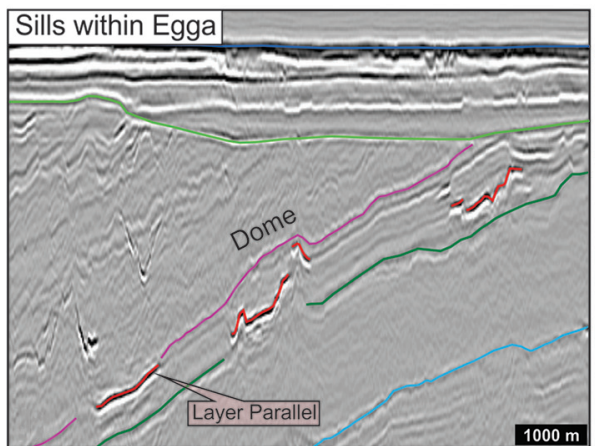

g)

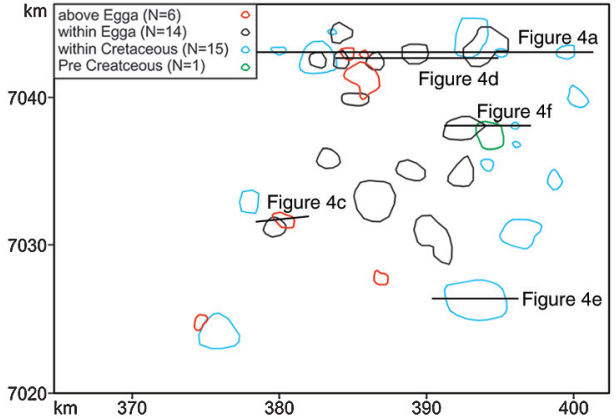

h) c)

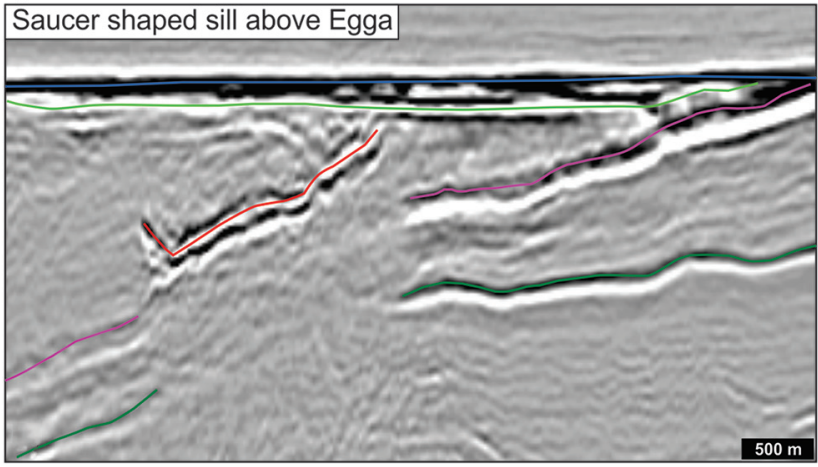

e)

f)
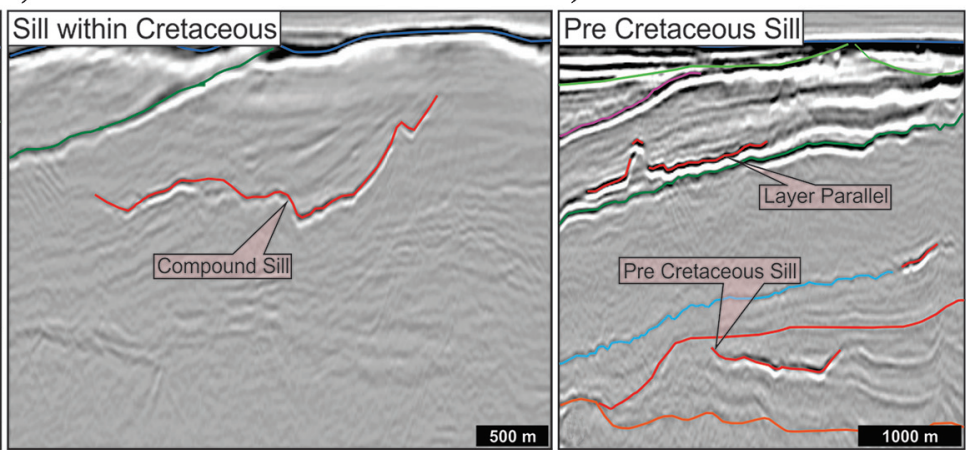

i)
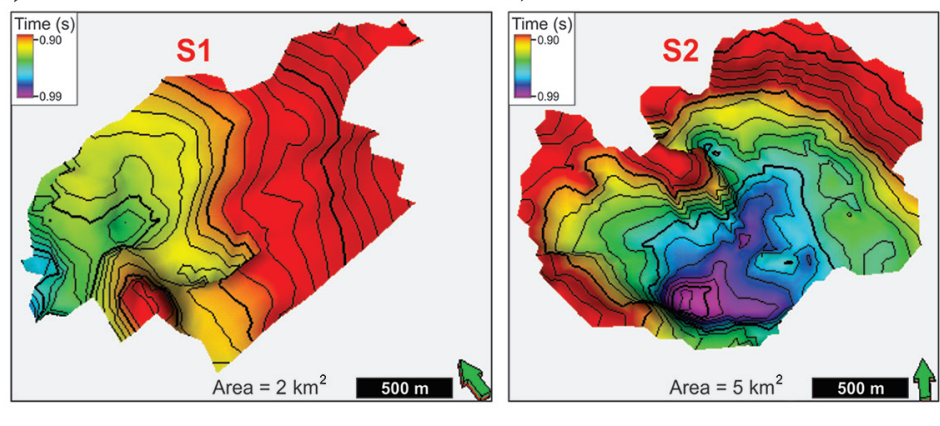

Figure 4. Sill interpretation examples. (a and b) Seismic sections and time slice showing characteristic saucer and planar transgressive sills and their distribution at different stratigraphic levels. (c) Saucer-shaped sill above Egga. (d-f) Sills within Egga, Cretaceous, and Pre-Cretaceous sediments, respectively. (g) Mapped distribution of sill complexes in the study area. (h and i) The 3D view of sills S1 (tilted) and S2, respectively. Location of seismic sections in Figure 4g. 
nature of the bounding surfaces, geometry, and extension. The main mapped horizons are described below.

The seabed is picked as a high-amplitude (peak) continuous reflection. It is poorly imaged in the southeastern part due to shallow water depth. The seabed is picked by autotracking with good confidence and continuity. A total of 21 seamounts were mapped and called the Vestbrona Seamounts. The seabed grid (depth) shows glacially eroded troughs and seamounts (Figure 2). The amplitude and rms amplitude maps reveal marks of glacial activity (plough marks and ridges developed by ice grinding). The ridges are present in the southwestern part of the study area and are cross-cut by the northeastsouthwest-oriented glacial furrows and plough marks. Glacially eroded troughs and plough marks describe the direction of ice streams moving northeast-southwest and east-southeast-west-northwest. Amplitude maps reveal the movement of three ice streams that adjoin in a bigger trough in the west of the study area. Small circular depressions such as pockmarks are abundant in the northeastern part of the study area. However, highresolution data are required for the confirmation of pockmarks in this area.

The URU is marked by toplap truncations of older strata with the horizontally overlying glacial sediments (Figure 4). The seismic amplitude of he URU is variable in nature. The reflection is extensively present in the whole study area except in the southeastern part where it merges with the seabed. The URU is a composite unconformity developed by the erosion of multiple glacial advances (approximately 30) during Plio-Pleistocene time on the continental shelf (Hafeez, 2011; Faleide et al., 2012). A huge number of sediments are eroded by the glacial activity from mainland Norway and deposited on the continental shelf in the form of westward-dipping clinoforms (Naust Formation) (Figure 4). Depressions are present at the level of URU developed by the glacial erosion of Plio-Pleistocene age (Hafeez, 2011; Faleide et al., 2012). The Molo Formation, consisting of sandstone and high-angle clinoforms, stands as a resistive ridge at the URU level (Figure 4).

Regional downlap surface (RDS) is mapped by the downlapping clinoforms of the Naust Formation (Figure 4). The Naust Formation consists of a Plio-Pleistocene succession of westward-prograding clinoforms gently dipping and downlapping to the RDS, dated back to approximately 2.8 Ma (Hafeez, 2011; Faleide et al., 2012).

Intra-1 (I1) is interpreted on the basis of seismic facies. It is the top of a sequence of high-amplitude, discontinuous, and faulted reflections (Figure 4). Intra-1 corresponds to the upper part of the piercement structures (level of subcropping) at the base of the Molo Formation. Intra-1 represents the top of a polygonally faulted, high-amplitude unit overlying a band of transparent facies. The reflection is identified in the western part of the study area and subcrops at URU. Regional well tie lines suggest a Top Tare (Lower Eocene) age.
Intra-2 (I2) is interpreted on the basis of similar criteria as Intra-1. It is located at the top of a unit of polygonally faulted, high-amplitude segmented reflection band separated by a transparent seismic facies unit from Top Egga (TE) (Figure 4). The reflection is interpreted in the west-central part of the survey. It is absent in the western part of the study area, where it merges into transparent facies. It disappears to the east prior to termination at the URU. It is not possible to tie the reflection to nearby wells, but it is tentatively assigned an intra (top) Tang (uppermost Paleocene) age. The Paleogene strata (Tare and Tang Formations) are highly faulted due to dewatering of sediments (Berndt et al., 2003).

The TE is a high-amplitude and continuous reflection marking the boundary between the Egga sandstone and the overlying transparent facies of the Tang Formation (Figure 4). The horizon can be picked with high confidence in the central part of the study area where it downlaps to the BTU. In the southern part, it may reappear as a mappable thin band of deep marine facies. At certain places, the continuity is disturbed by the presence of sills. The internal stratification pattern is downlapping on the BTU. The thickness of the Egga Member increases up dip and thins down dip, finally disappearing in the northwestern part of the study area. Exploration wells along the Norwegian margin show that the Danian is the most sandstone-prone interval of the Paleocene.

The BTU is a continuous and high-amplitude reflection marking the boundary between the Upper Cretaceous shales and the Egga Member (Figure 4). The westwardprograding clinoforms are downlapping to the BTU and define the surface as a maximum flooding surface. The BTU is extensive in the study area except in the southeast where lower Tertiary sediments have been eroded and Cretaceous sediments subcrop at the seabed or at URU.

The Top Lange (TL) can also be traced with high confidence as a high-amplitude and continuous reflection that downlaps on the Top Basement toward the west (Figure 4). A package of Cretaceous strata bounded by the TL and $\mathrm{BCU}$ is thinning toward the west and eventually pinches out at the BCU or Top Basement.

The BCU is variable in nature (amplitude) but can be easily picked as an erosional surface on the seismic except in the areas where seismic imaging is poor due to sill intrusions. The BCU merges with the Top Basement on the western flank of the Frøya High.

The Top Basement comprises the deepest mapped reflection and forms a continuous high-amplitude reflector in the seismic data (Figure 4). It is mappable over most of the study area except where occluded by overlying volcanic intrusions and piercement structures.

\section{Sill complexes}

Numerous sill complexes at various stratigraphic levels are interpreted based on their characteristic reflection shapes and high amplitudes (Figure 4; Planke et al. $2005,2015)$. Sills are generally characterized by continuous, very high-amplitude reflections that exhibit concordant and discordant relationships with sedimentary 
reflections. Other criteria are also applied to differentiate sills from other high-amplitude events such as lavas, sandstones, carbonates, injectites, or gas layers. To interpret a seismic reflection as a sill, we have used the following main characteristics:

1) high amplitude (peak)

2) transgression (locally cross-cutting sedimentary strata)

3) saucer shaped

4) abrupt terminations.

Layer parallel, planar transgressive, and compound geometries are also identified (Figure 4; Planke et al., 2005). The sills have typically circular or irregular geometries on time slices. Sill complexes appear as high-amplitude semicircular complexes on maximum amplitude maps generated for different stratigraphic intervals.

Sills are widely distributed in the eastern part of the study area having variable sizes $\left(0.1-9 \mathrm{~km}^{2}\right)$ and stratigraphic depths (Figure 4g). In total, 36 sills have been interpreted and mapped to determine the stratigraphic level and extent of the intrusions. The largest sill complex of $9 \mathrm{~km}^{2}$ lies within Cretaceous sediments in the southeastern part of study area. This sill complex is compound in nature and creates a problem for seismic imaging of the deeper sequences. Another sill complex, with an areal extent of $6 \mathrm{~km}^{2}$, occurs in the Egga Member. Many smaller sill complexes are present in the Paleogene and Cretaceous sediments with a size range of $0.1-0.5 \mathrm{~km}^{2}$.

The sills are present at different stratigraphic levels, but they are most widely distributed in Cretaceous sequences and within the Danian sandstones of the Egga Member (Figures 4 and 9). Some shallow sills are also present at the Intra-2 level (Upper Paleocene), however, few (and uncertain) sills are present in the sequence between Intra-1 and Intra-2 (Figure 4c). No sills are identified stratigraphically above Intra-1. Sills are not common in pre-Cretaceous sequences, and only one sill complex is identified below BCU (Figure 4f). Doming of overburden sediments ("forced folds") related to sill intrusions is also observed (Figure 4d).

A total of 45 piercement structures are identified in the study area. The uppermost part of these structures is typically a high-amplitude, mounded reflection (Figure 5a). The exceptions are a few flat-topped examples at the URU or Seabed levels. Seismic imaging below the top of the structures is poor, and no deeper reflections can be mapped with confidence. Upward-bending reflections are common in the pipe structures, but these are possibly migration artifacts. A detailed description and an interpretation of these structures are not the focus of this paper.

\section{Geologic Results Igneous samples}

The igneous dredge samples (Figure 5b) contain a variety of textures, typically glomeroporphyritic (clusters of large crystals in a fine-grained matrix). Examples of these olivine-rich textures are shown in Figure 6 . The olivine and feldspars were found to be remarkably fresh (Figure 6b), providing the potential for confident geochemical and geochronological analysis.

Original XRF analysis was reported for the Vestbrona samples by Prestvik et al. (1999). Some of the powders used in these original studies were supplied in the sample set received for this study, and these were used for new analysis. The original rocks were classified as melilite nephelinite (type 1), olivine nephelinite (type 2), and basanite (Prestvik et al., 1999). In this study, three new XRF analyses were carried out to confirm existing data with the latest standards, providing a reassessment of the rock type classification. The following samples were chosen to represent the three previously reported igneous rock types: 153/2A melilite nephelinite (type 1), 153-2B - olivine nephelinite (type 2), and 154/ 3B - basanite.

The summary results for the new analysis are shown in Figure 6c. The rocks plot with elevated alkali signatures but are not far from picrite-picrobasalt compositions. Olivine-rich compositions are often found at the onset and early stages of flood volcanism (Jerram et al., 1999; Jerram and Widdowson, 2005; Hole et al., 2015); however, they are less commonly highly alkaline. Examples of such elevated alkali compositions can be found in other rift settings such as the African rift valley (Baker et al., 1972) and are characterized by relatively low volume melts, with the timings of these occurrences being variable (Fitton and Upton, 1987). A high bulk density of up to approximately $3 \mathrm{~kg} / \mathrm{m}^{3}$ is calculated for the samples using the MAGMA (KWare Geological Software Information, 2017) petrological modeling program, a consequence of the high $\mathrm{MgO}$ olivine-rich nature of the rocks. PRIMELT (Herzberg and Asimow, 2008) primary magma calculations do not produce viable solutions for the Vestbrona samples and are in any case not applicable where the presence of hydrous melting is likely, and, therefore, an accurate estimate of the mantle potential temperature during melting is not possible (Hole and Millett, 2016). However, the high MgO wt.\% of the rocks, coupled with the presence of high forsterite olivines (Fo\% approximately 78-90; Prestvik et al., 1999) and a well-developed HREE garnet signature (Prestvik et al., 1999), demonstrates the possibility that the magmas were generated at higher than ambient mantle temperatures. The porphyritic nature of the samples and a lack of fresh groundmass glass restrict the potential for accurate emplacement temperature estimates based, e.g., on olivine-liquid equilibrium (Roeder and Emslie, 1970; Keiding et al., 2011); however, assuming that the high Fo olivines are not inherited, for which there is no clear evidence (e.g., kinking), emplacement temperatures could have been up to approximately $1200^{\circ} \mathrm{C}$.

Samples 153-2A and 154-3A were chosen for geochronological age dating with $\mathrm{Ar} / \mathrm{Ar}$ analysis. The rationale for the dating was that the original age analysis of the 
Vestbrona Formation was done using K-Ar techniques reported by Bugge et al. (1980) (original sample analyzed: 154/3). As such, the estimate of the timing of igneous activity can potentially be questioned, as old K-Ar techniques can yield anomalous ages, and with only one sample age, the data were limited and need to be checked.

A whole rock analysis of sample 153-2A (Figure 6d) yields four concordant steps and gives a weighted mean plateau of $56.6 \pm 0.55 \mathrm{Ma}$ (analytical error). The inverse isochron analysis yields similar results, $57.2 \pm 0.61 \mathrm{Ma}$ (analytical error). This can be considered a robust age because the two techniques overlap. The spectrum analysis of 154-3A whole rock yields concordant overlapping apparent ages from step 2-4, which gives a weighted mean plateau age of $59.2 \pm 0.57 \mathrm{Ma}$ (analytical error). The same steps yield an inverse isochron age of $61.1 \pm 2.93 \mathrm{Ma}$ (note significant error). This age data were less reliable but again suggest an older age than the published 55.7 Ma K-Ar age. The rocks are therefore provisionally considered to be emplaced approximately $57 \mathrm{Ma}$ during the early phase of magmatism in the basin and closer to early magmatic pulses of the NAIP (Saunders et al., 1997).

\section{Sedimentary samples}

The dredged sediment samples (Figures $5 \mathrm{~b}$ and 7) consist of a light buff-brown sample and a black crudely bedded and indurated sample. The buff-brown sample $154 / 3$ Sed-1 is a fine-grained mudstone, with a bleached and mottled appearance. The oxides are patchy and

a)

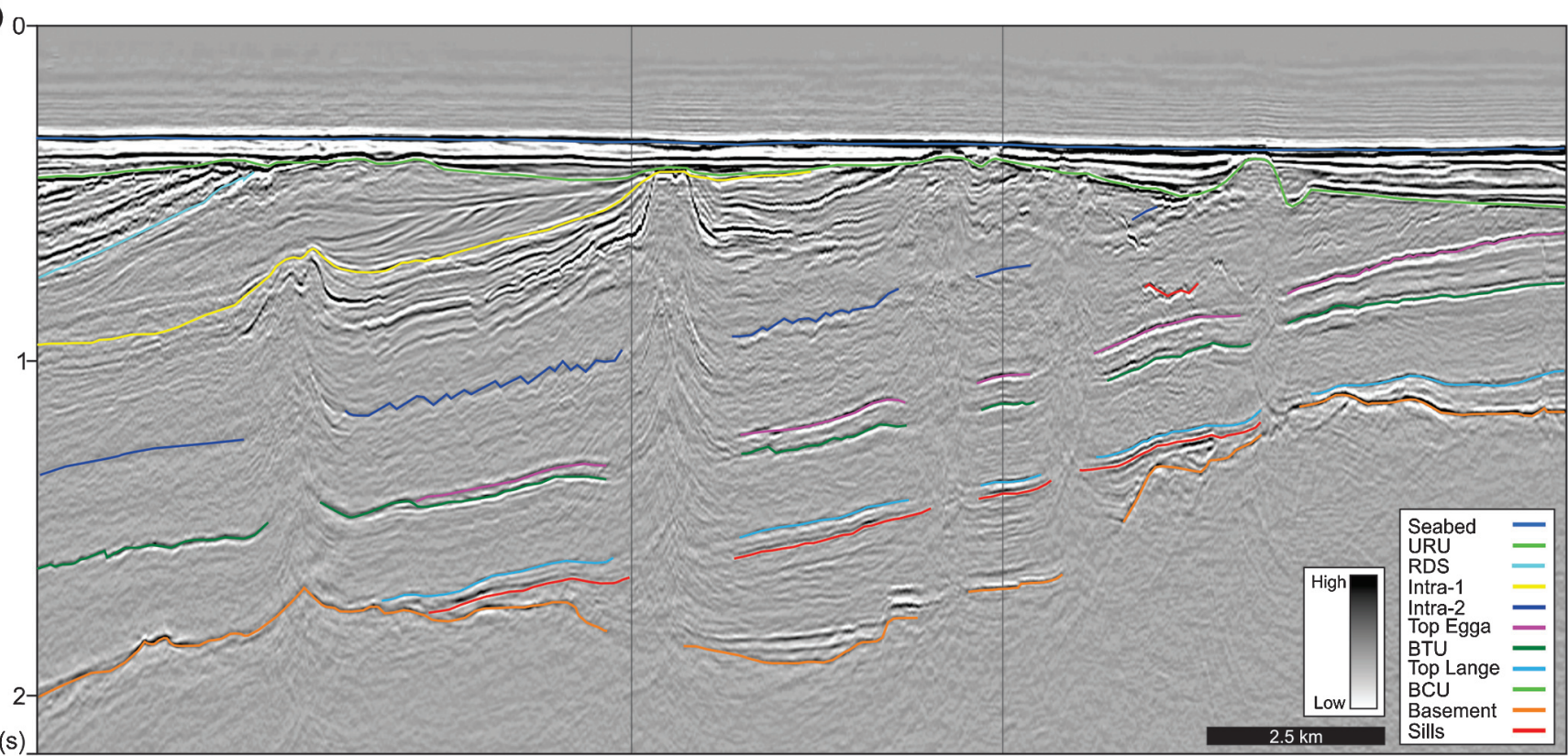

b) $0 \mathrm{~W}$

$\Delta$

$\Delta$

$\mathrm{E}$

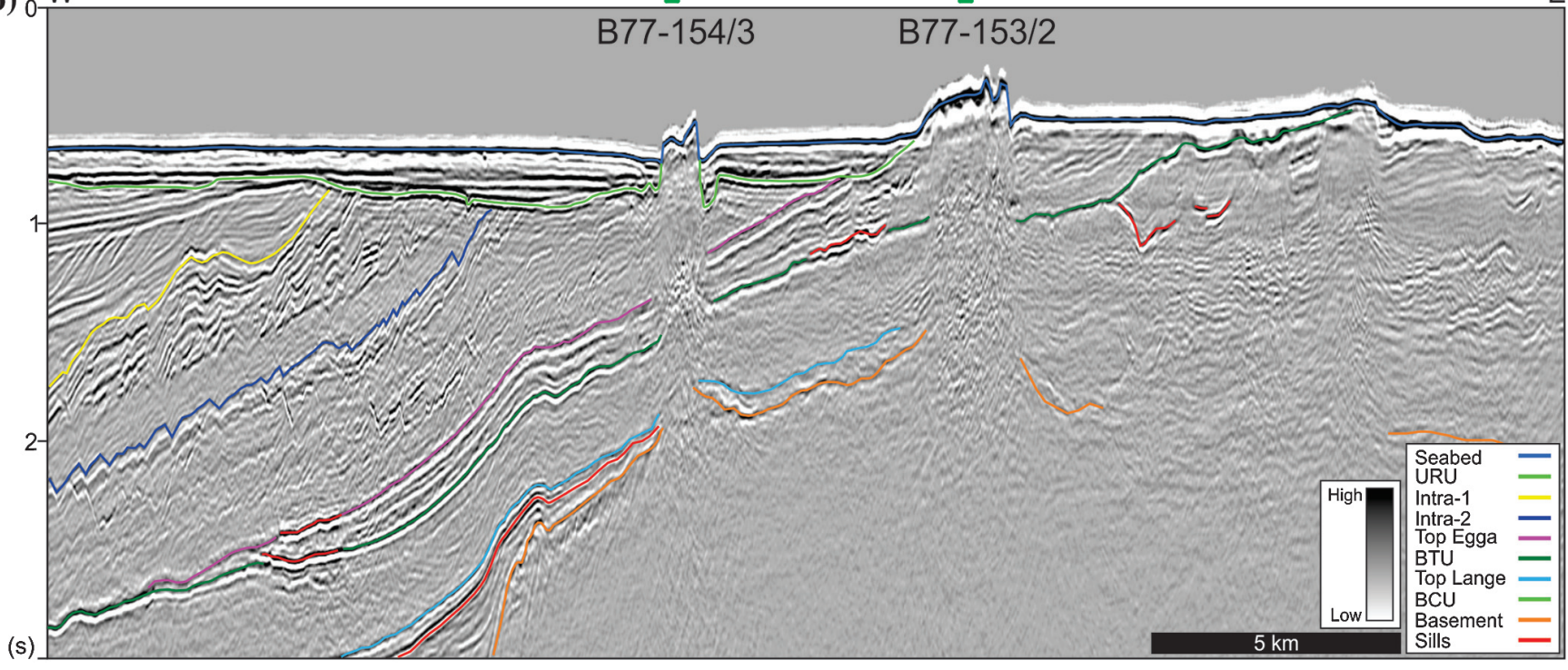

Figure 5. (a) Seismic section showing piercement structures (the black vertical lines show the bends of arbitrary lines) and (b) the location of sampling sites. See Figure 2 for the location. 
have a spotted appearance. A closeup inspection reveals isolated vugs (and clustered distribution of oxides). The sample is relatively soft and appears like a marl. Thin section analysis (Figure 7) clearly reveals the distribution of patchy clustered oxides, within a very fine-grained matrix. Secondary calcite can be observed in patches, and the isolated vugs are particularly clear from cross-polarized light. The vugs must be isolated in $3 \mathrm{D}$ because they have not been impregnated successfully with blue resin applied to the sample during the thin-section preparation. The redistribution of oxides and calcite precipitation can occur at the hot contacts with igneous bodies (Jerram and Stollhofen, 2002). The development of the vugs could be related to dissolution/ precipitation reactions.

Sample 154/3 Sed-2 is a fine-grained mudstone/shale, with occasional larger grains and fragments. There is some crude bedding visible in the small hand specimen, but very little else can be seen in the hand view. Thin section analysis reveals lithic and quartz fragments in a very fine black matrix. Again, the sample has not taken any blue-dye staining during thin-section preparation, suggesting that any porosity present is very limited in terms of connectivity.

The XRD results are given in Figure 7d. More clay was extracted from the 154/3 Sed-1 sample, as from an equal volume of 154/3 Sed-2. This indicates that the phyllosilicates in the Sed-2 sample are micas and chlorite, rather than clay minerals; i.e., Sed-2 has been baked and metamorphically altered. The identification of abundant feldspar can make identification of other minerals difficult in XRD; in this instance, the identification of microcline makes it difficult to be certain whether ankerite and siderite are truly present in the sandstone. The illitesmectite may be derived from alteration of the ferromagnesian minerals, either from within the sediments or a)

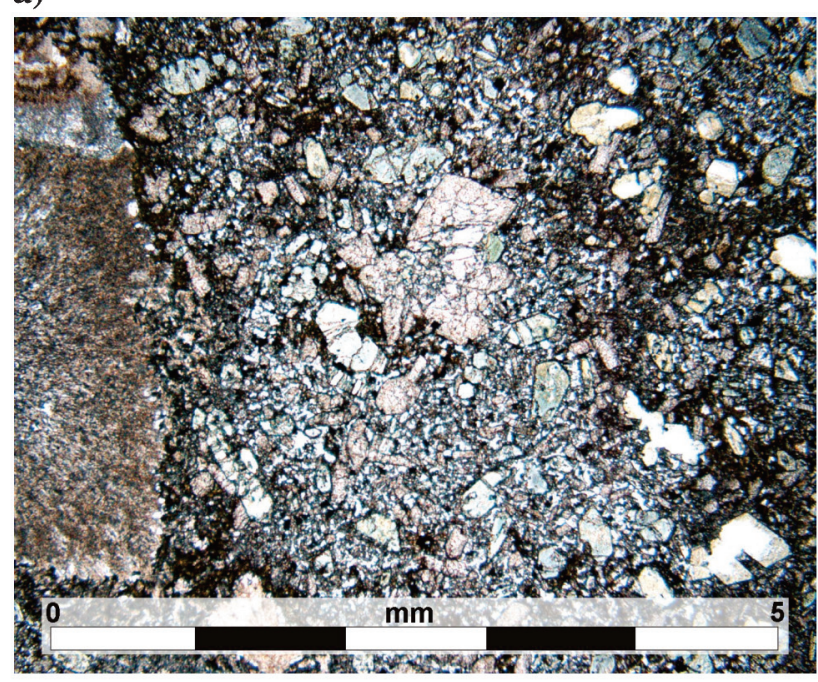

c)

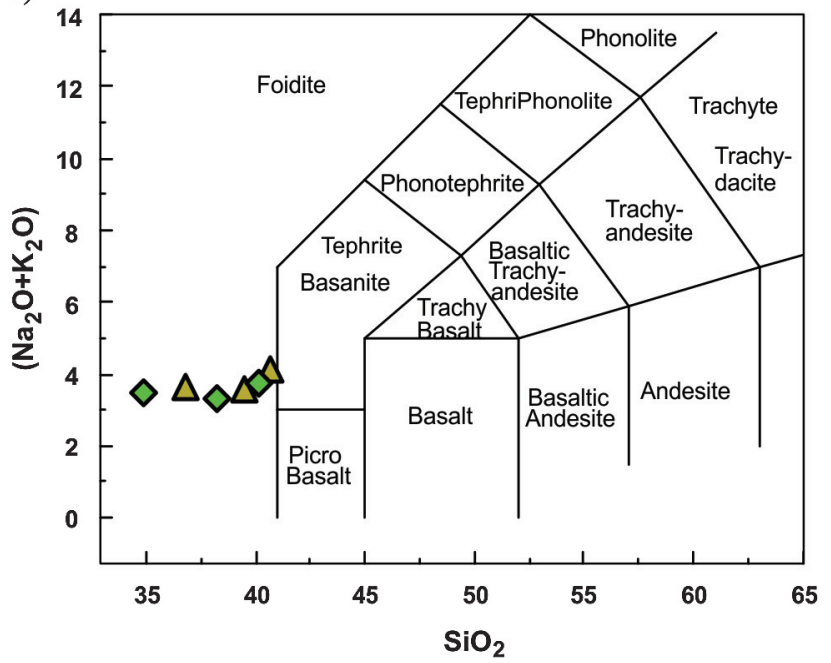

b)

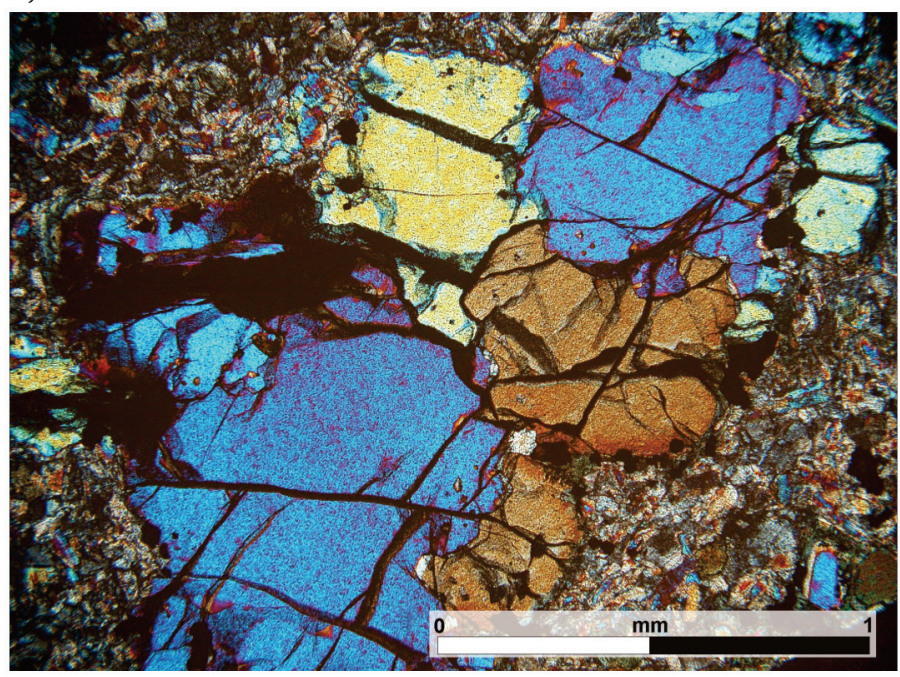

d)

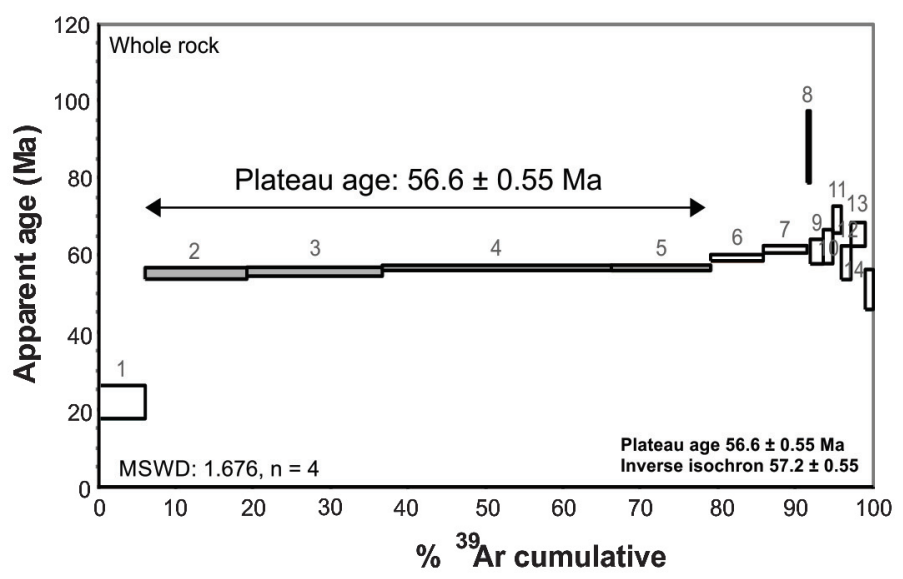

Figure 6. Dredged igneous rocks of the Vestbrona Formation. (a) plane polarized light image of type 2 Olivine nephelinite, (b) close-up of the same sample in crossed polars highlighting the extremely fresh nature of the sample, (c) total alkali silica classification plot of samples (diamonds, this study; triangles, previous published data from Prestvik et al., 1999), and (d) Ar/ Ar age determination. 
reworked from weathered igneous rock. Because the grain size is so fine in these two samples, further study of these samples with SEM and EDAX would be required, so a complete identification of the clay/mica phases can be realized.

The sample "154/3 Sed-1" did not yield organic materials, and nothing can be said about its origin from palynological examination. However, the sample "154/3 Sed2 " provided some vital new information with regard to its palynological analysis (Figure 7c). The black homogeneous shale yielded a relatively rich organic residue. All the organics are grayish black (metamorphosed) and fragmented indicating exposure to elevated temperatures, a preservational state that is often seen in the proximity of intrusive rocks. This can be seen quite clearly with metamorphosed fragments of wood (Figure 7c).

The sample is of marine origin as evidenced by the numerous fragments of dinoflagellate cysts, and it can be dated to the earlier parts of the Late Paleocene (approximately $61 \mathrm{Ma}$ ) on the presence of common Palaeoperidinium pyrophorum and common Areoligera spp (Figure 7c). This assemblage is known from a rather narrow zone approximately 61 million years. The pollen genus Trudopollis is also represented, which has its main distribution in the Maastrichtian, but it is also well-known from the Paleocene.

\section{Discussion}

Igneous rocks and processes in the Frøya High area have been studied using new 3D seismic reflection data and a reanalysis of vintage dredged samples. Detailed mapping of 10 seismic horizons, which were tied to nearby wells, were used to obtain a local stratigraphic framework. Within this context, we can consider the emplacement and type of igneous bodies, the evolution of the Vestbrona Formation, and its petroleum implications.

\section{Subcropping sill}

The seismic data reveal the presence of an extensive sill complex in a $500 \mathrm{~km}^{2}$ region in the eastern part of the study area. In total, 36 sills have been mapped. The sills are dominantly present in Cretaceous and Paleocene sequences. However, one sill is also mapped in preCretaceous strata. No well-defined sills are found above the Intra-2 (late Paleocene?) level. The sills are fairly small, with a maximum aerial size of approximately $9 \mathrm{~km}^{2}$ and scattered compared with the sill complexes found in the Vøring and Møre Basins (Planke et al., 2005). It is difficult to determine the thickness of the sills based on the seismic

d) data, but they are likely quite thin (estimated as 25-40 m thick). Sills below this thickness range are below the vertical resolution of common seismic surveys and potentially will not be imaged (Planke et al., 2015; Schofield et al., 2015). The sill complexes are layer parallel, saucershaped, planar transgressive, and compound in geometry. No feeder dikes are identified. Characteristic domes or "forced folds" are observed above many of the saucershaped sill complexes (Hansen and Cartwright, 2006; Jackson et al., 2013).

Igneous rocks of the Vestbrona Formation have been sampled by dredges (Bugge et al., 1980). These rocks were interpreted to represent igneous plugs (Bugge et al., 1980) but have also been speculated to be lava flows based on a recent MAREANO ROV survey (Thorsnes et al., 2012).

We interpret the sampled igneous rocks to be erosional remnants of sill intrusions. Figure 8a shows a seismic profile across one of the sampled seamounts. The seamount is located in an area with subcropping Egga Member rocks. Sill intrusions are common in the Egga Member, and several shallow sills are identified within this sequence a few kilometer downdips (Figure 8a). Igneous rocks are erosionally resistant, and sill-capped a)

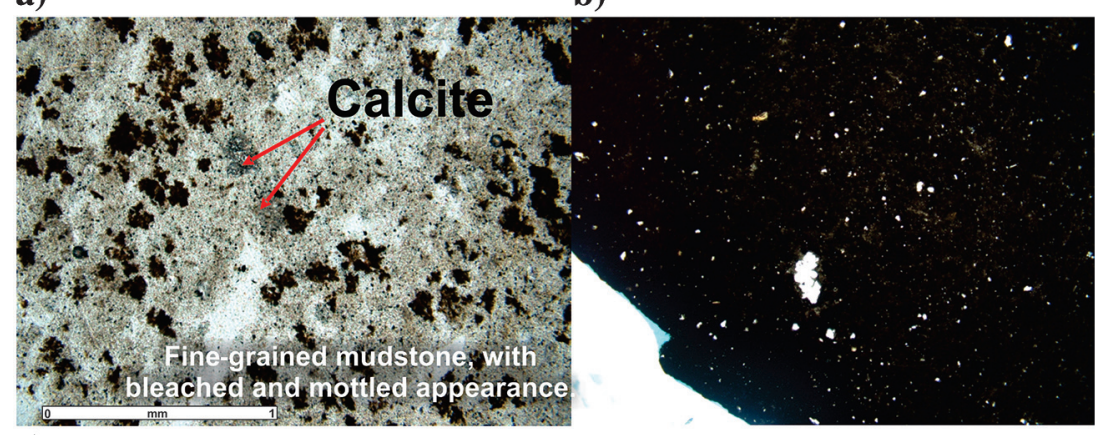

c)

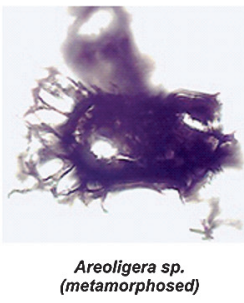

Areoligera sp.
(metamorphosed)

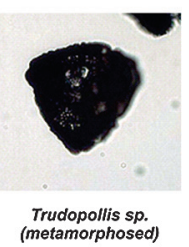

Trudopollis sp.
(metamorphosed)
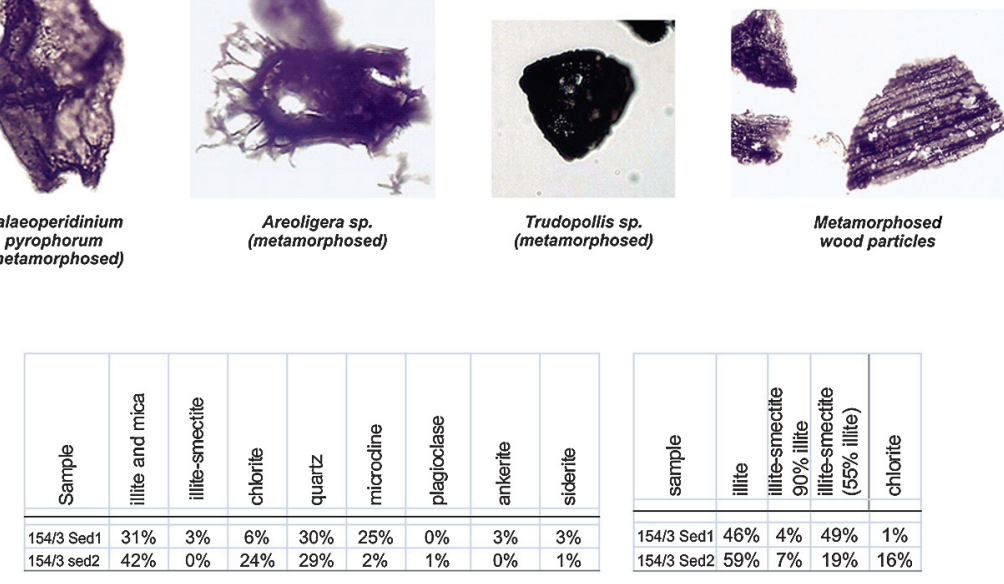

Figure 7. Dredge sedimentary rocks in the Vestbrona Seamounts. (a) Light-buffcolor mudstone with mottled appearance of oxide nodules and with carbonate and vugs highlighted, (b) dark-colored fine grains and fragments, (c) paleontological examples of organic material extracted from the sediment in (b), and (d) XRD data for the two sediment types. 
mounts are common in volcanic basins such as the socalled "kopi" (table top) mountains in the Karoo Basin, South Africa (Figure 8b). We suggest that these kopi mountains are terrestrial analogs to the sampled seamounts in the Frøya High region.

The erosional sill model is supported by palynological analyses of the dredged sedimentary rocks. The palynological age of one sediment samples is $61 \mathrm{Ma}$, i.e., uppermost Danian. The Egga Member is of Danian to Early Selandian age (Vergara et al., 2001), supporting the interpretation that the analyzed sediment samples are near in situ. Evidence from the sediment samples suggest that they may have been thermally metamorphosed, and we suggest that this was caused in situ by heat from the igneous intrusions of the Vestbrona Formation.

An implication of the erosional sill model is that the disturbed seismic below the seamount is an imaging problem. The high impedance and rough topography of the sill will cause strong scattering of the seismic energy and poor, or no, imaging of the deeper structures. A continuity of the deeper sequences can possibly be

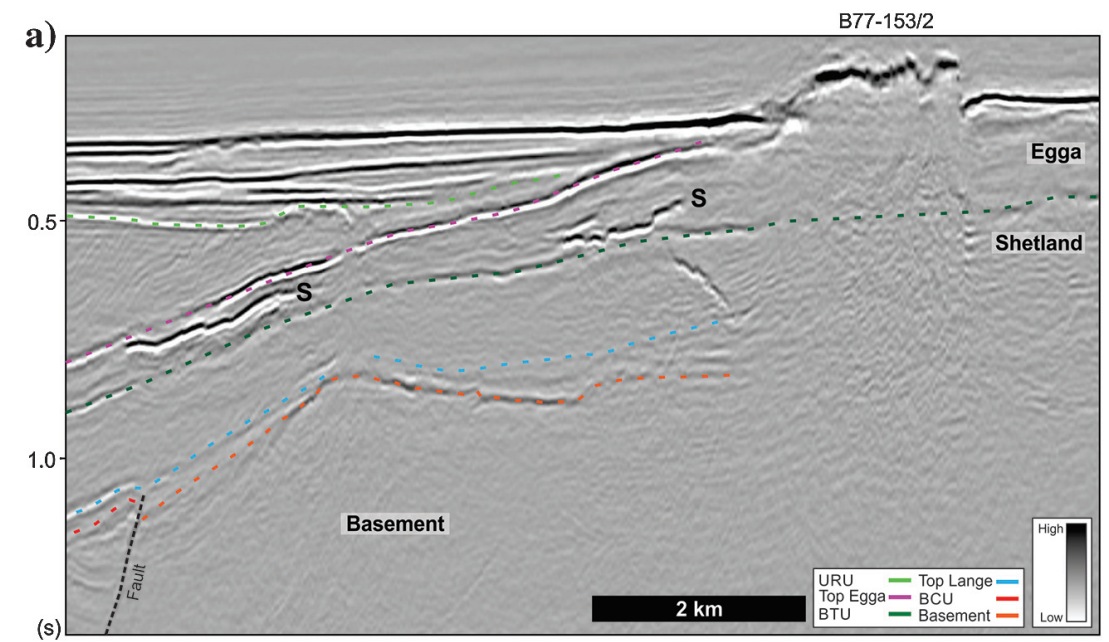

b)

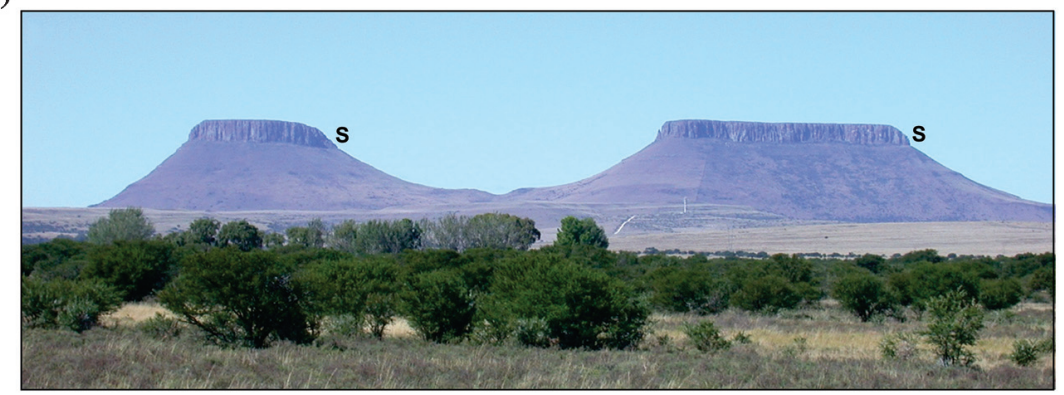

Figure 8. Interpretation of the sampled seamounts as erosional sill remnants. (a) Seismic profile showing the dredged seamount is stratigraphically located within the Egga Member. Several intra-Egga sills are located just down-dip from the seamount. See Figure 2 for the location. (b) Picture of two kopi's in the Karoo, South Africa. The kopi's are capped by erosionally resistant inner, flat parts of one or more saucer-shaped sills (approximately $100 \mathrm{~m}$ high cliffs at the top). The dolerite sheets were intruded into horizontally layered sedimentary strata (exposed in the slopes below the dolerite sheets). We suggest that these mountains are analogs to the two sampled Vestbrona Seamounts (Photo: S. Planke). determined by special seismic acquisition and processg (e.g., undershooting of the seamount).

The Ar-Ar dating suggests a prebreakup age of approximately $57 \mathrm{Ma}$ of the igneous rocks. This is older the previously published K-Ar age of $55.7 \pm 0.9$ dePcribed by Bugge et al. (1980). Igneous activity of Late aleocene age is known from the entire NAIP and indiBasin (Planke et al., 2005).

The new and published geochemistry and petrography of the Vestbrona Formation show that they are exotic alkaline porphyritic igneous rocks. These silicaundersaturated rocks are often found in association with large igneous provinces.

\section{Evolutionary model}

Figure 9 shows a schematic evolutionary model of the Vestbrona Formation and associated piercement structures. Two types of vertical pipe-like regions of disturbed strata are imaged. One is a geologic piercement structure likely related to fluid escape, whereas the other is due to seismic imaging problems below erosional igneous remnants at the seabed:

1) The initial stage is infilling of a sedimentary basin throughout Cretaceous and Paleocene times (Figure 9a).

2) The second stage is low-volume intrusive magmatism of high-temperature melts forming sill complexes in a $500 \mathrm{~km}^{2}$ large area prior to breakup (approximately $57 \mathrm{Ma}$ ). The seismic interpretation suggests that the piercement structures likely formed during the same time period (Figure 9b).

3) The third stage is slow sedimentation until mid-Miocene times. The piercement structures may have been reused for fluid seepage (Figure 9c).

4) The final stage is uplift and tilting of the margin and glacial erosion and deposition of glacial sediments. Sill complexes are more resistant to erosion and will form seamounts on the seabed in which intruded Cretaceous and Paleocene sediments subcrop at the seabed (Figure 9d).

\section{Petroleum implication}

Sill intrusions can have wide-ranging implications for petroleum systems and are becoming increasingly investigated for their effects on petroleum systems worldwide (Schutter, 2003; Delpino and Bermúdez, 2009; Senger et al., forthcoming). Specifically, they may cause heating of host rock sediments in the metamorphic aureole and can cause the genera- 
tion of large volumes of hydrocarbons where sills are intruded into organic-rich sediments (Svensen et al., 2004; Rodriguez Monreal et al., 2009; Aarnes et al., 2015). Sills and associated dikes may also create barriers and baffles to fluid flow, potentially significantly altering the migration pathways (Filho et al., 2008; Rateau et al., 2013). Sills may also create a range of trapping features including directly associated features in which the intrusion morphology creates the trap (Schutter, 2003; Senger et al., forthcoming) and traps in which, for example, host sedi-

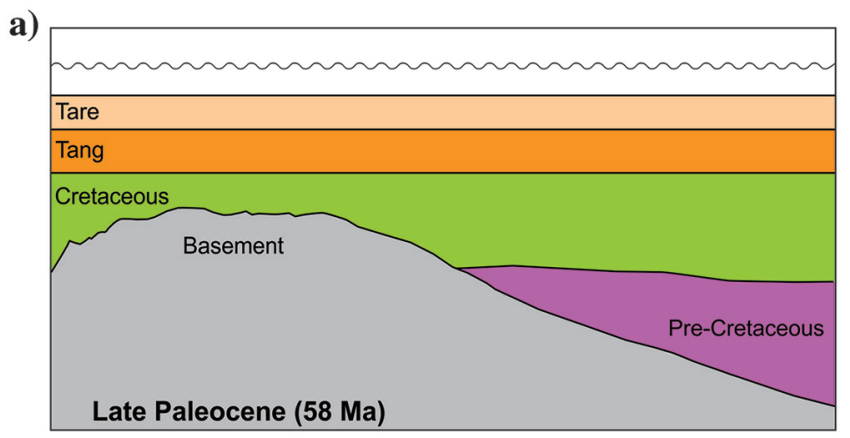

b)

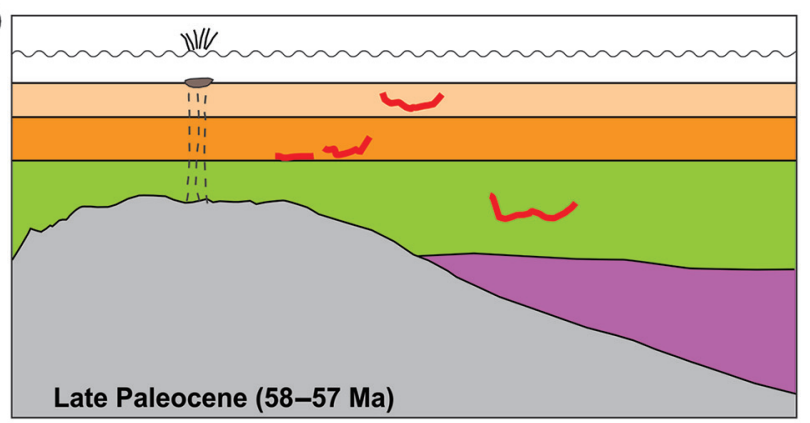

c)

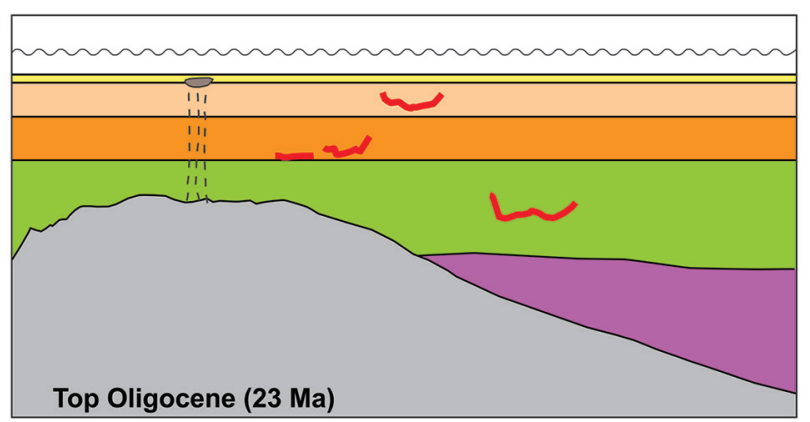

d)

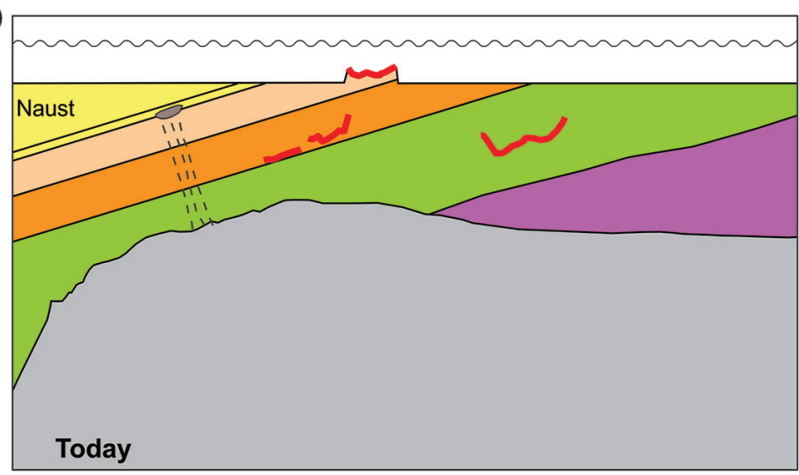

Figure 9. Schematic evolutionary model of the Vestbrona Formation in the Frøya High region. ments are "jacked up" by sill inflation, often called forced folds, which can create four-way closures in the overburden above sills (Hansen and Cartwright, 2006; Jackson et al., 2013). Finally, intrusions are also known to form reservoirs in several regions globally such as Argentina (Witte et al., 2012) and Thailand (Schutter, 2003), where hydrocarbons are produced from fracture and cavity networks within the intrusions.

The Vestbrona Formation magmatism may have had a similar effect on the prospectivity of the Frøya High. However, the effect of the igneous activity is mainly restricted to the Cretaceous and Paleocene sequences because few sills are identified in the pre-Cretaceous units (only one is identified; but there might be more). One uncertainty is whether the sills are also present within the Jurassic source rocks in the study area. Sills are commonly observed to preferentially intrude organicrich units within field examples (Schofield et al., 2015; Eide et al., 2016). However, we have identified only one sill in the Jurassic, and even if there are more present, thin layer-parallel sills would be difficult to identify. For instance, it has been demonstrated that sills $<40 \mathrm{~m}$ in thickness are commonly below the vertical resolution limit of seismic data within the Faroe-Shetland Basin, (Schofield et al., 2015). Given the generally small size of the sill complex and a lack of clear evidence for large-scale fluid migration features directly associated with them, it is likely that the effects of the intrusions were relatively localized. Whether deeper intrusions or subseismic interconnected sheet intrusions have caused source rock compartmentalization or contributed to a "shadow zone" for hydrocarbon migration above the intrusion networks (Rateau et al., 2013), remains unconstrained from the current data set.

\section{Conclusions}

Within this study, we present a detailed multidisciplinary investigation focusing on the Vestbrona Formation in the Frøya High region, offshore mid-Norway. The results of our study can be summarized as follows:

1) The igneous rocks of the Vestbronna Formation comprise a sill complex dominantly intruded into Cretaceous and Paleocene sediments.

2) Previously sampled seamounts are demonstrated to form the erosional remnants of an extensive sill complex that extends down into the subsurface. The sill complex was tectonically tilted and then exhumed by erosion, resulting in the formation of the Vestbronna Seamounts.

3) Seismic imaging problems below the erosional remnants of the high-velocity igneous rocks create vertical zones of disturbed reflections, obscuring identification of underlying reflectors.

4) New XRF and Ar-Ar dating on dredge samples from the Vestbrona Seamounts reveal that the sills are of prebreakup age (approximately $57 \mathrm{Ma}$; approximately 1-2 Ma older than breakup) and were formed from small-volume alkalic melts. 
5) New biostratigraphy and XRD analysis of sediment dredge samples from the Vestbrona Seamounts suggest that these samples are approximately 61 million years old, were sampled near in situ, and have been exposed to elevated temperatures, inferred to relate to the emplacement of the Vestbrona Formation sills. The age of the sediments is therefore consistent with the igneous rock ages being less than $61 \mathrm{Ma}$.

6) The identified sill complex has affected the petroleum system within the study area dominantly by source rock maturation within the thermal aureoles of the intrusions and by altering of the potential migration pathways within the area.

7) Suggestions for future study include basin modeling studies focused on the impact of the mapped sill complexes on the temperature history and fluid migration history of the basin, with particular focus on sills intruding Mesozoic rocks. The erosional sill remnant model could also be further constrained by seismic undershooting experiments or seismic reprocessing.

\section{Acknowledgments}

We are very grateful for data access and publishing permission from Tullow Oil. Furthermore, access to the dredge samples by NTNU (T. Prestvik and M. B. Mørk) is also greatly appreciated. The detailed biostratigraphy was done by H. Selnes (APT), and it was an important contribution to the project. Discussions and data from Spring Energy throughout the project period are also greatly appreciated. We further acknowledge the support from the Research Council of Norway through its Centers of Excellence funding scheme, project 22372, and from the MIMES project. We are also thankful to J. M. Hugget for his contribution to analyze clay samples.

\section{References}

Aarnes, I., S. Planke, M. Trulsvik, and H. Svensen, 2015, Contact metamorphism and thermogenic gas generation in the Vøring and Møre basins, offshore Norway, during the Paleocene-Eocene thermal maximum: Journal of the Geological Society, 172, 588-598, doi: 10 .1144/jgs2014-098.

Aarnes, I., Y. Podladchikov, and H. Svensen, 2012, Devolatilization-induced pressure build-up: Implications for reaction front movement and breccia pipe formation: Geofluids, 12, 265-279, doi: 10.1111/j.1468-8123.2012 .00368.x.

Abdelmalak, M. M., S. Planke, J. I. Faleide, D. A. Jerram, D. Zastrozhnov, S. Eide, and R. Myklebust, 2016, The development of volcanic sequences at rifted margins: New insights from the structure and morphology of the Vøring Escarpment, mid-Norwegian Margin: Journal of Geophysical Research: Solid Earth, 121, 5212-5236, doi: 10.1002/2015JB012788.

Askvik, H., and K. Rokoengen, 1985, Geologisk kart over Norge, berggrunnskart Kristiansund, scale 1:250 000: Geological Survey of Norway.
Baker, B. H., P. A. Mohr, and L. A. J. Williams, 1972, Geology of the eastern rift system of Africa: The Geological Society of America, Special Paper, 136, 67.

Berndt, C., S. Bunz, and J. Mienert, 2003, Polygonal fault systems on the mid-Norwegian margin: A long-term source for fluid flow, in P. Van Rensbergen, R. R. Hillis, A. J. Maltman, and C. K. Morley, eds., Subsurface sediment mobilization: Geological Society, Special Publications 216, 283-290.

Blystad, P., H. Brekke, R. B. Færseth, B. T. Larsen, J. Skogseid, and B. Tørudbakkken, 1995, Structural elements of the Norwegian continental shelf: NPD-Bulletin, 8, 12.

Brekke, H., H. I. Sjulstad, C. Magnus, and R. W. Williams, 2001, Sedimentary environments offshore Norway, in O. J. Martinsen, and T. Dreyer, eds., Sedimentary environments offshore Norway - Paleozoic to recent: Norwegian Petroleum Society (NPF) Special Publication: Elsevier 10, 7-37.

Bugge, T., M. Løfaldi, G. H. Maisey, K. Rokoengen, F. E. Skaar, and B. Thusu, 1975, Geological investigation of a Lower Tertiary-Quaternary core, offshore Trøndelag, Norway: Norges Geologiske Unders $ø$ kelse, 316, 253-269.

Bugge, T., T. Prestvik, and K. Rokengen, 1980, Lower Tertiary volcanic rocks off Kristiansud-Mid Norway: Marine Geology, 35, 277-286, doi: 10.1016/0025-3227(80)90121-8.

Bugge, T., and K. Rokoengen, 1976, Geological mapping offshore Troms, Northern Norway: Continental Shelf Institute Publication 91, 21.

Delpino, D. H., and A. M. Bermúdez, 2009, Petroleum systems including unconventional reservoirs in intrusive igneous rocks (sills and laccoliths): The Leading Edge, 28, 804-811, doi: 10.1190/1.3167782.

Doré, A. G., E. R. Lundin, L. N. Jensen, Ø. Birkeland, P. E. Eliassen, and C. Fichler, 1999, Principal tectonic events in the evolution of the northwest European Atlantic margin, in Petroleum Geology Conference series: Geological Society London 5, 41-61.

Eide, C. H., N. Schofield, D. A. Jerram, and J. A. Howell, 2016, Basin-scale architecture of deeply emplaced sill complexes: Jameson Land, East Greenland: Journal of the Geological Society, 174, 1-18, doi: 10.1144/jgs2016018.

Eidvin, T., T. Bugge, and M. Smelror, 2007, The Molo formation, deposited by coastal progradation on the inner Mid-Norwegian continental shelf, coeval with the Kai formation to the west and the Utsira formation in the North Sea: Norwegian Journal of Geology, 87, 75-142.

Faleide, J. I., J. P. Nystuen, and A. Hafeez, 2012, The late Plio-Pleistocene outbuilding of the mid-Norwegian continental shelf: Seismic sequence stratigraphy reflecting 30 glaciations: Presented at the 30th Nordic Geological Winter Meeting.

Filho, A. T., A. M. P. Mizusaki, and L. Antonioli, 2008, Magmatism and petroleum exploration in the Brazilian Paleozoic basins: Marine and Petroleum Geology, 25, 143-151, doi: 10.1016/j.marpetgeo.2007.07.006. 
Fitton, J. G., and B. G. Upton, 1987, Alkaline igneous rocks: Geological Society of London, Special Publication.

Foulger, G. R., and D. L. Anderson, 2005, A cool model for the Iceland hotspot: Journal of Volcanology and Geothermal Research, 141, 1-22, doi: 10.1016/j.jvolgeores 2004.10.007.

Gabrielsen, R. H., R. Kyrkjebø, J. I. Faleide, W. Fjeldskaar, and T. Kjennerud, 2001, The Cretaceous post-rift basin configuration of the northern North Sea: Petroleum Geoscience, 7, 137-154, doi: 10.1144/petgeo.7.2.137.

Gernigon, L., F. Lucazeau, F. Brigaud, J. C. Ringenbach, S. Planke, and B. Le Gall, 2006, A moderate melting model for the Vøring margin (Norway) based on structural observations and a thermo-kinematical modelling: Implication for the meaning of the lower crustal bodies: Tectonophysics, 412, 255-278, doi: 10.1016/j.tecto.2005.10.038.

Hafeez, A., 2011, Late Cenozoic sedimentary outbuilding offshore Mid-Norway: A sequence stratigraphic analysis: M.S. thesis, University of Oslo.

Hansen, D. M., and J. Cartwright, 2006, The three dimensional geometry and growth of forced folds above saucer shaped igneous sills: Journal of Structural Geology, 28, 1520-1535, doi: 10.1016/j.jsg.2006.04.004.

Hansen, D. M., J. Redfern, F. Federici, D. Di Biase, and G. Bertozzi, 2008, Miocene igneous activity in the Northern Subbasin, offshore Senegal, NW Africa: Marine and Petroleum Geology, 25, 1-15, doi: 10.1016/j.marpetgeo .2007.04.007.

Hartley, R. A., G. G. Roberts, N. White, and C. Richardson, 2011, Transient convective uplift of an ancient buried landscape: Nature Geoscience, 4, 562-565.

Herzberg, C., and P. D. Asimow, 2008, Petrology of some oceanic island basalts: PRIMELT2.XLS software for primary magma calculation: Geochemistry, Geophysics, Geosystems, 9, Q09001, doi: 10.1029/2008GC002057.

Hole, M. J., and J. M. Millett, 2016, Controls of mantle potential temperature and lithospheric thickness on magmatism in the North Atlantic Igneous Province: Journal of Petrology, 57, 417-436, doi: 10.1093/petrology/egw014.

Hole, M. J., J. M. Millett, N. W. Rogers, and D. W. Jolley, 2015, Rifting and mafic magmatism in the Hebridean basins: Journal of the Geological Society, 172, 218-236, doi: 10.1144/jgs2014-100.

Hole, M. J., and M. A. Morrison, 1992, The differentiated dolerite boss, Cnoc Rhaonastil, Islay: A natural experiment in the low pressure differentiation of an alkali olivine-basalt magma: Scottish Journal of Geology, 28, 5569, doi: 10.1144/sjg28010055.

Howell, S. M., G. Ito, A. J. Breivik, A. Rai, R. Mjelde, B. Hanan, K. Sayit, and P. Vogt, 2014, The origin of the asymmetry in the Iceland hotspot along the Mid-Atlantic Ridge from continental breakup to present-day: Earth and Planetary Science Letters, 392, 143-153, doi: 10 .1016/j.epsl.2014.02.020.

Jackson, C. A., C. Magee, N. Schofield, and B. Golenkov, 2013, Seismic expression and petroleum system implications of igneous intrusions in sedimentary basins:
Examples from offshore Australia, in Search and Discovery Article \#10483: AAPG.

Jamtveit, B., H. Svensen, Y. Y. Podladchikov, and S. Planke, 2004, Hydrothermal vent complexes associated with sill intrusions in sedimentary basins: Physical Geology of High-Level Magmatic Systems, 234, 233-241.

Jerram, D. A., 2015, Hot rocks and oil: Are volcanic margins the new frontier?: Elsevier R\&D Solutions, http:// www.elsevier.com/rd-solutions/oil-and-gas/explorationand-production, accessed 15 September 2016.

Jerram, D. A., and S. E. Bryan, 2015, Plumbing systems of shallow level intrusive complexes, in K. Nemeth, ed., Advancess in Volcanology: Springer, 1-22.

Jerram, D. A., N. Mountney, and H. Stollhofen, 1999, Facies architecture of the Etjo Sandstone Formation and its interaction with the Basal Etendeka Flood Basalts of northwest Namibia: Implications for offshore prospectivity: Geological Society, London, Special Publications 153, 367-380.

Jerram, D. A., and H. Stollhofen, 2002, Lava/sediment interaction in desert settings; are all peperite-like textures the result of magma-water interaction?: Journal of Volcanology and Geothermal Research, 114, 231-249, doi: 10.1016/S0377-0273(01)00279-7.

Jerram, D. A., and M. Widdowson, 2005, The anatomy of Continental Flood Basalt Provinces: Geological constraints on the processes and products of flood volcanism: Lithos, 79, 385-405, doi: 10.1016/j.lithos.2004.09.009.

Karlsen, D., B. Nylend, B. Flood, S. E. Ohm, T. Brekke, S. Olsen, and K. Backer-owe, 1995, Petroleum geochemistry of the Haltenbanken, Norwegian continental shelf, in J. M. Cubitt, and W. A. England, eds., The geochemistry of reservoirs: Geological Society London, Special Publication 86, 203-256.

Keiding, J. K., R. B. Trumbull, I. V. Veksler, and D. A. Jerram, 2011, On the significance of ultra-magnesian olivines in basaltic rocks: Geology, 39, 1095-1098, doi: 10.1130/G32214.1.

Kelley, S., 2002, K-Ar and Ar-Ar Dating: Reviews in Mineralogy and Geochemistry, 47, 785-818, doi: 10.2138/ rmg.2002.47.17.

Kennish, M. J., R. A. Lutz, and B. R. T. Simoneit, 1992, Hydrothermal activity and petroleum generation in the Guaymas Basin: Reviews in Aquatic Sciences, 6, 467-477.

KWare Geological Software Information, 2017, http://www .lanl.gov/orgs/ees/geodynamics-/Wohletz/KWare/Index .htm, accessed 20 January 2017.

Kyrkjebø, R., R. H. Gabrielsen, and J. I. Faleide, 2004, Unconformities related to Jurassic-Cretaceous syn/ post-rift transition of the Northern North Sea: Journal of Geological Society London, 161, 1-17, doi: 10 .1144/0016-764903-051.

Lien, T., 2005, From rifting to drifting: Effects on the development of deep-water hydrocarbon reservoirs in a passive margin setting, Norwegian Sea: Norwegian Journal of Geology, 85, 319-332. 
Lundin, E., and A. G. Doré, 1997, A tectonic model for the Norwegian passive margin with implications for the NE Atlantic: Early Cretaceous to break-up: Journal of Geological Society London, 154, 545-550, doi: 10.1144/gsjgs .154.3.0545.

Lundin, E., and A. G. Doré, 2002, Mid-Cenozoic postbreakup deformation in the 'passive' margins bordering the Norwegian-Greenland Sea: Marine and Petroleum Geology, 19, 79-93, doi: 10.1016/S0264-8172(01) 00046-0.

Magee, C., J. D. Muirhead, A. Karvelas, S. P. Holford, C. A. L. Jackson, I. D. Bastow, and N. Schofield, 2016, Lateral magma flow in mafic sill complexes: Geosphere, 12, 809-841, doi: 10.1130/GES01256.1.

Martinsen, O. J., 2008, Norway rises from the sea. Palaeogene and Neogene (Cenozoic) — The modern continents take shape: 66-2.6 million years ago, in I. B. Ramberg, I. Bryhni, A. Nøttvedt, and K. Rangnes eds., The making of a land - Geology of Norway: The Norwegian Geological Association, 442-479.

Menzies, M. A., S. L. Klemperer, C. J. Ebinger, and J. Baker, 2002, Characteristics of volcanic rifted margins: Geological Society of America Special Paper 362, 1-14.

Müller, R., J. P. Nystuen, F. Eide, and H. Lie, 2005, Late Permian to Triassic basin infill history and basin paleogeography of the Mid-Norwegian shelf-East Greenland region: Norwegian Petroleum Society (NPF) Special Publication, 12, 165-189, doi: 10.1016/S0928-8937(05) 80048-7.

Nelson, C. E., D. A. Jerram, J. A. P. Clayburn, A. M. Halton, and J. Roberge, 2015, Eocene volcanism in offshore southern Baffin Bay: Marine Petroleum Geology, 67, 678-691, doi: 10.1016/j.marpetgeo.2015.06.002.

Nielsen, T. F. D., 1987, Tertiary alkaline magmatism in E Greenland: A review, in J. G. Fitton, and B. G. J. Upton, eds., Alkaline igneous rocks: Geological Society Special Publication 30, 498-515.

Norwegian Petroleum Directorate, 2016a, Norwegian Sea - Paleocene plays, http:/www.npd.no/en/Topics/ Geology/Geological-plays/Norwegian-Sea/Paleocene/, accessed 19 January 2017.

Norwegian Petroleum Directorate, 2016b, Norwegian Sea - Upper Jurassic plays, http://www.npd.no/en/ Topics/Geology/Geological-plays/Norwegian-Sea/UpperJurassic/, accessed 19 January 2017.

Nøttvedt, A., and E. P. Johannessen, 2008, The source of Norway's oil wealth. Late Jurassic - A sea of islands emerges 161-146 million years ago, in I. B. Ramberg, I. Bryhni, A. Nøttvedt, and K. Rangnes, eds., The making of a land - Geology of Norway: The Norwegian Geological Association, 284-417.

Planke, S., T. Rasmussen Eidem, S. S. Rey, and R. Myklebust, 2005, Seismic characteristics and distribution of volcanic intrusions and hydrothermal vent complexes in the Vøring and Møre basins, in A. G. Dore, and B. A. Vining, eds., Petroleum geology: North-west Europe and global perspectives: Proceedings of the 6th Petroleum Geology Conference Geological Society London, 833-844.

Planke, S., H. Svensen, R. Myklebust, S. Bannister, B. Manton, and L. Lorenz, 2015, Geophysics and remote sensing: Advances in volcanology: Springer, 1-16.

Planke, S., P. A. Symonds, E. Alvestad, and J. Skogseid, 2000, Seismic volcanostratigraphy of large-volume basaltic extrusive complexes on rifted margins: Journal of Geophysical Research, 105, 19335-19351, doi: 10 .1029/1999JB900005.

Prestvik, T., T. Torske, B. Sudvoll, and H. Karlsson, 1999, Petrology of early Tertiary nephelinites off mid-Norway. Additional evidence of an enriched endmember of the ancestral Iceland plume: Lithos, 46, 317-330, doi: 10 .1016/S0024-4937(98)00088-7.

Rateau, R., N. Schofield, and M. Smith, 2013, The potential role of igneous intrusions on hydrocarbon migration, West of Shetland: Petroleum Geoscience, 19, 259272, doi: 10.1144/petgeo2012-035.

Rise, L., D. Ottesen, K. Berg, and E. Lundin, 2005, Largescale development of the mid-Norwegian shelf and margin during the last 3 million years: Marine Petroleum Geology, 22, 33-44, doi: 10.1016/j.marpetgeo.2004.10 .010 .

Rodriguez Monreal, F., H. J. Villar, R. Baudino, D. Delpino, and S. Zencich, 2009, Modeling an atypical petroleum system: A case study of hydrocarbon generation, migration and accumulation related to igneous intrusions in the Neuquen Basin, Argentina: Marine and Petroleum Geology, 26, 590-605, doi: 10.1016/j.marpetgeo.2009.01.005.

Roeder, P., and R. Emslie, 1970, Olivine-liquid equilibrium: Contributions to Mineralogy and Petrology, 29, 275289, doi: 10.1007/BF00371276.

Saunders, A. D., J. G. Fitton, A. C. Kerr, M. J. Norry, and R. W. Kent, 1997, The North Atlantic igneous province, in J. J. Mahoney, and M. F. Coffin, eds., Large igneous provinces: Continental, oceanic, and planetary flood volcanism: American Geophysical Union Geophysical Monographs 100, 45-93.

Saunders, A. D., S. M. Jones, L. A. Morgan, K. L. Pierce, M. Widdowson, and Y. G. Xu, 2007, Regional uplift associated with continental large igneous provinces: The roles of mantle plumes and the lithosphere: Chemical Geology, 241, 282-318.

Schmiedel, T., S. Kjoberg, S. Planke, C. Magee, O. Galland, N. Schofield, C. A.-L. Jackson, and D. A. Jerram, 2017, Mechanisms of overburden deformation associated with the emplacement of the Tulipan sill, mid-Norwegian margin: Interpretation, 5, no. 3, SK23-SK38, doi: 10.1190/INT-2016-0155.1.

Schofield, N., S. Holford, J. M. Millett, D. Brown, D. R. Jolley, S. Passey, D. Muirhead, C. Grove, C. Magee, J. Murray, and M. Hole, 2015, Regional magma plumbing and emplacement mechanisms of the Faroe-Shetland Sill Complex: Implications for magma transport and 
petroleum systems within sedimentary basins: Basin Research, 29, 41-63, doi: 10.1111/bre.12164.

Schofield, N., D. A. Jerram, S. Holford, S. Archer, N. Mark, A. Hartley, J. Howell, D. Muirhead, P. Green, D. Hutton, and C. Stevenson, 2016, Sills in sedimentary basins and petroleum systems: Advances in Volcanology: Springer International Publishing.

Schutter, S. R., 2003, Hydrocarbon occurrence and exploration in and around igneous rocks, in N. Petford, and K. J. W. McCaffrey, eds., Hydrocarbons in crystalline rocks: Geological Society, Special Publications, 7-33.

Senger, K., J. Millett, S. Planke, K. Ogata, C. Eide, M. Festøy, O. Galland, and D. A. Jerram, forthcoming, Effects of igneous intrusions on the petroleum system: A review: First Break, 36, no. 6.

Smelror, M., J. Dehls, J. Ebbing, E. Larsen, E. R. Lundin, Ø. Nordgulen, P. T. Osmundsen, O. Olessen, D. Ottesen, C. Pascal, T. F. Redfield, and L. Rise, 2007, Towards a 4D topographic view of the Norwegian Sea margin: Global and Planetary Change, 58, 382-410, doi: 10.1016/j .gloplacha.2006.12.005.

Svensen, H., S. Planke, A. Malthe-Sørenssen, B. Jamtveit, R. Myklebust, T. Eidem, and S. S Rey, 2004, Release of methane from a volcanic basin as a mechanism for initial Eocene global warming: Nature, 429, 542-545, doi: 10.1038/nature02566.

Thorsnes, T., V. Bellec, and M. Dolan, 2012, Gransket gammel vulkan på Mørebanken, http://www.ngu.no/nyheter/ gransket-gammel-vulkan-p\%C3\%A5-m\%C3\%B8rebanken, accessed 20 September 2012.

Torske, T., and T. Prestvik, 1991, Mesozoic detachment faulting between Greenland and Norway: Inferences from Jan Mayen fracture Zone System and associated alkalic volcanic rocks: Geology, 19, 481-484, doi: 10 .1130/0091-7613(1991)019<0481:MDFBGA>2.3.CO;2.

Trude, J., J. Cartwright, R. J. Davies, and J. Smallwood, 2003, New technique for dating igneous sills: Geology, 31, 813-816, doi: 10.1130/G19559.1.

Trulsvik, M., S. Planke, D. Jerram, R. Mykklebust, and S. Polteau, 2012, Geophysical atlas of the Møre and Vøring Basins: Integrated seismic, gravity and magnetic interpretation, MV12, 22nd round ed.: Volcanic Basin Petroleum Research and TGS.

Underhill, J. R., 1998, Jurassic, in K. W. Glennie, ed., Petroleum geology of the North Sea, basic concepts and recent advances, 4th ed.: Blackwell Science Limited, 245-293.

Vergara, L., I. Wreglesworth, M. Trayfoot, and G. Richardsen, 2001, The distribution of Cretaceous and Paleocene deep-water reservoirs in the Norwegian Sea basins: Petroleum Geoscience, 7, 395-408, doi: 10.1144/ petgeo.7.4.395.

Witte, J., M. Bonora, and C. Carbone, 2012, Fracture evolution in oil-producing sills of the Rio Grande Valley, northern Neuquén Basin, Argentina: AAPG Bulletin, 96, 1253-1277, doi: 10.1306/10181110152.

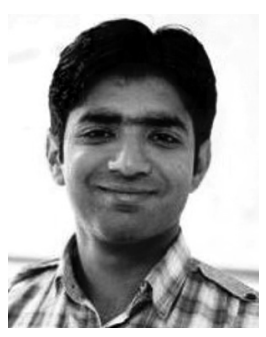

Amer Hafeez received a bachelor's degree in geology (2006) and holds two master's degrees in petroleum geology from Punjab University Lahore, Pakistan (2008) and the University of Oslo, Norway (2011). His geologic career started as a geologist with Volcanic Basin Petroleum Research (VBPR) in 2011 and moved to Tullow Oil Norge in 2013. Currently, he is working with VBPR from December 2016. He has a good experience of oil and gas exploration from Norwegian Continental Shelf. His main strengths are in 2D and 3D seismic interpretation, seismic facies and attribute analysis, prospect evaluation, petroleum systems, seismic stratigraphy, risk analysis, volumetrics, geologic report writing, and license management.

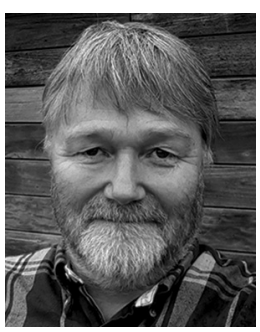

Sverre Planke received a B.S. (1985) in geologic engineering and an M.S. (1987) in geophysics, both from the University of Utah, and a Ph.D. (1993) in geology from the University of Oslo. $\mathrm{He}$ is the CEO of VBPR and is an adjunct professor at the Centre for Earth Evolution and Dynamics (CEED), University of Oslo, Norway. He is a geoscientist with research focus on the processes and structure of volcanic rifted margins and volcanic basins based on integrated geologic, geophysical, and theoretical methods. He is a cofounder of VBPR (1999) and P-Cable 3D Seismic (2007).

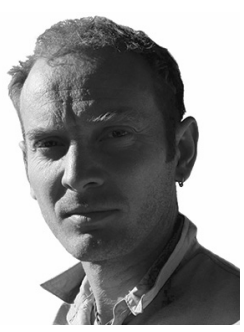

Dougal Jerram is the director of DougalEARTH Ltd. (www.dougalearth .com), and a Prof II at the Centre for Earth Evolution and Dynamics, University of Oslo. He is an award-winning Earth Scientist (Geol. Soc. Murchison Fund 2006) and has worked for many years on projects that link academia and industry as an expert in volcanic rocks and volcanic margins. With his many publications, and as an author of books, he also undertakes science outreach activities through the media. The most recent major venture is called Volcanic Margin Petroleum Prospectivity (VMAPP), which is a multiclient project undertaken with VBPR and TGS, looking at our state-of-the-art understanding of volcanics in the petroleum context.

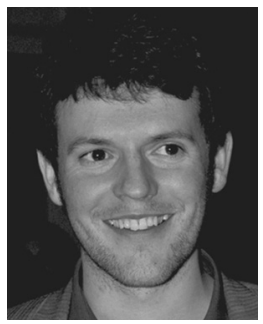

John M. Millett received a first-class B.S. (honors) in geology and petroleum geology from the University of Aberdeen in 2010 followed by a Ph.D. in 2014. He currently works for VBPR AS and holds an Honorary Research Fellow position at the University of Aberdeen. He is a member of the Mineralogical Society and is a member of the VMSG committee. He has wide experience in volcanic 
basins with expertise covering igneous geochemistry, stratigraphy, petrophysics, borehole analysis, and petroleum systems.

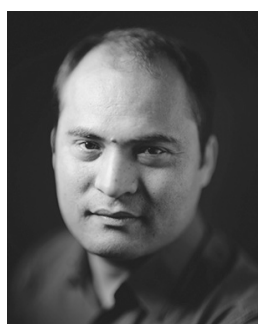

Dwarika Maharjan received his undergraduate degree (2005) in geosciences at Tribhuwan University, Nepal, and completed a master's degree (2011) in geosciences at the University of Oslo, Norway. His geologic career began in 2011, with Volcanic Basin Petroleum Research in 2011 in Oslo, Norway. He has been actively involved in seafloor sampling projects (offshore sampling operations and reporting) and is working on $2 \mathrm{D}$ and $3 \mathrm{D}$ seismic data interpretation and data management for various multiclient and consulting projects. He is an associate researcher for Glaciated North Atlantic Margins (GLANAM).

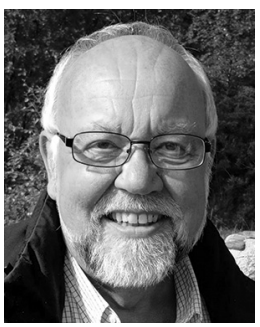

Tore Prestvik graduated from the University of Oslo in 1970 with a major in geology. From 1969, he held positions as research assistant, assistant professor, associate professor, and full professor (from 1987) in geology at the University of Trondheim. After an education-based Ph.D. program was formally established at Norwegian
Universities around 2000, he supervised seven Ph.D. students until he retired in 2009. His teaching was in mineralogy and petrology, whereas his research focused on igneous petrology, mainly of volcanic rocks. He published textbooks (in Norwegian) in geology, mineralogy, petrology, and geochemistry. He has published approximately 60 scientific papers - thereof 27 as first author - in refereed journals. He held a one-year research fellowship in volcanology at The Nordic Volcanological Institute in Iceland 1974/75. He was a visiting professor at Center for Volcanology of the University of Oregon (1979/80) and spent several sabbaticals at Texas Tech University (12 months in 1988/89 and 2003/2004, six months in 1998 and 2008). He participated as a specialist in volcanology of the Norwegian Polar Institute's expedition to Bouvet Island 1978/79. He is (or has been) a member of the Geological Society of Norway, Geological Society of America, American Geophysical Union, and Fellow of the Mineralogical Society of America. In 1993, he was elected as a member of the Royal Norwegian Society of Science and the Humanities (DKNVS). 